\title{
Petri Hoppu
}

\section{Hallitut ja vallattomat ruumiit ${ }^{1}$ Tanssi, yhteiskunta ja historia}

Tanssintutkimuksen ikuinen kiistakysymys on tanssin ja yhteiskunnan välinen suhde. Onko tanssi todellisuutta sui generis vai onko se yhteiskunnallisen todellisuuden heijastumaa? Tanssiantropologia on lyhyen historiansa aikana tarkastellut tanssia olennaisena osana ympäröivää yhteiskuntaa. Se elää kulttuurisena tuotteena niissä ihmisissä, jotka tanssivat. Se on aina luonteeltaan sosiaalista, oli sitten kyseessä soolo-, pari- tai suuremman ryhmän tanssi. (Vrt. Hanna 1979, 3-4; Royce 1977, 13.) Onko tanssi kuitenkin vain sosiaalisen todellisuuden heijastaja, kuten Paul Spencer (1985, 38; myös Rust 1969, 1) tuntuu ajattelevan sanoessaan, että tanssintutkimuksessa olennaisinta on kääntyä kohti yhteiskuntaa, vai onko tanssilla itsellään suurempaa yhteiskunnallista tai muuta merkitystä?

Tässä kirjoituksessa käsittelen erästä mahdollista tarkastelutapaa, joka voisi tarjota ratkaisua esitettyihin kysymyksiin; esimerkkinä käytän menuetin kukoistusaikaa hovitanssina 1600-luvulta 1800-luvun alkuvuosiin ja hieman myöhemminkin. Käsittelyssäni yhdistän tanssin historialliseen tarkasteluun yhteiskunnallisen kontekstin analysointia siten, että tanssi on keskeisenä tekijänä kokonaisuudessa eikä vain ympäröivän todellisuuden heijastajana. Tätä kautta yritän välttää niitä karikoita, joihin tanssiantropologia on usein törmännyt. Pidän tanssia merkittävänä osana yhteiskunnan ruumiillista kokemista, joka on keskeisenä todellisuuden sosiaalisessa rakentumisessa (Eichberg 1987, 31-32). Ruumiillisuuden yhteiskunnallinen ulottuvuus onkin artikkelini yksi keskeisimmistä teemoista. On myös huomattava, että jossain määrin tanssi on myös sui generis, eli siinä on aina piirteitä, jotka liittyvät vain tanssiviin ihmisiin. Tanssi on osa sellaista kokemusta, jota ei läheskään tyhjentävästi pystytä selittämään sanallisesti.

Tarkastelussani yhdistän siis kolme näkökulmaa, joita pidän keskeisimpänä tanssin vaiheita tutkittaessa: ruumiillisuuden sekä yhteiskunnallisen ja historiallisen kontekstin (vrt. Combs-Schilling 1989, 26-30; Bloch 1986, 9-11). Menuetissa nämä näkökulmat muodostavat mielenkiintoisen yhteyden, koska monissa suhteissa se on varsin poikkeuksellinen muihin tansseihin verrattuna. Menuetin vaiheet liittyvät erittäin selvästi eurooppalaiseen kulttuurihistoriaan 1600-luvulta aina 1800-luvun lopulle. Se oli aikanaan hovikulttuurin ruumiillistuma, mutta siitä tuli myös kokonaisen ajattelu- ja käyttäytymiskulttuurin symboli, jonka syrjäyttivät lopullisesti vasta modernin ajan ensimmäiset tuulet. Se ei kuitenkaan ollut pelkästään yläluokan tanssi, vaan jopa talonpoikien keskuudessa se saavutti suosiota ainakin joillakin alueilla. Tanskassa, Ruotsissa ja Suomessa sillä oli 1700 -luvulla varsin vahva asema, ja paikoin sitä on

\footnotetext{
${ }^{1}$ Artikkeli liittyy suomalaista menuettia käsittelevään väitöskirjatyöhöni, johon olen saanut rahoitusta Suomen Kulttuurirahastolta, Tampereen yliopistolta, Tampereen yliopiston Tukisäätiöltä sekä Seurasaarisäätiöltä.
} 
tanssittu aina tälle vuosisadalle asti.

Menuetti ei koskaan ollut vain yksi tanssi muiden joukossa; siihen ei missään suhtauduttu välinpitämättömästi, vaan se jakoi mielipiteitä erittäin voimakkaasti aivan syntyajoistaan lähtien (esim. Taubert 1968, 163-164). Näin tapahtui hyvinkin erilaisissa olosuhteissa ja eri aikoina niin aateliston kuin talonpoikaisväestönkin keskuudessa. On selvää, että tanssissa itsessään on jotain erityistä, jos sen ympärillä käydään näin voimakasta keskustelua ja niin laajalti. Toisaalta menuetti ei ollut monoliittinen kokonaisuus, vaan se sisälsi erilaisia muunnelmia ja tanssityylejä, jotka poikkesivat toisistaan enemmän tai vähemmän. Karkeasti tyylit voidaan jakaa "hallittuihin" ja "vallattomiin" sen mukaan, korostettiinko niissä tanssillista kuria vai tanssin nautintoa. Menuettiin liittyneet diskurssit ovat lähteneet nimenomaan tanssin ruumiillisuudesta, vaikkakin ne ovat alkaneet myös elää omaa elämäänsä. ${ }^{2}$

Tanssin ja sen yhteiskunnallisen kontekstin suhde on mielenkiintoinen, koska se joskus saattaa vaikuttaa hyvinkin sattumanvaraiselta ja epäjohdonmukaiselta: tanssiin liittyvät merkitykset tuntuvat irrallisilta ja epämääräisiltä, eikä niitä pystytä liittämään yleiseen sosiaaliseen kehykseen tarkasteltaessa tiettyä yhteiskunnallista tilannetta. Diakroninen näkökulma osoittaa kuitenkin, että tanssin merkitykset eivät ole syntyneet täysin sattumanvaraisesti. Tarkastelutapani kolmiyhteys tulee tässä esille. Ruumis on tanssin merkitysten tuottaja ja lähde, mutta yhteiskunta ja sosiaaliset tilanteet ovat ne, joissa merkitykset - kuten myös ruumiitkin - elävät, välittyvät ja muokkaantuvat. Historia osoittaa yhteiskunnan jatkuvan muuntumisen ja "epäfunktionaalisuuden", kun eri merkitysjärjestelmät eivät muodostakaan harmonista kokonaisuutta: eri historiallissosiaalisissa tilanteissa elää yhtä aikaa monelta eri ajalta peräisin olevia rakenteita, jotka ovat jatkuvan muutoksen alaisia (vrt. Turner 1983, 154-155). ${ }^{3}$

Jatkuva vähittäinen ja joskus nopeakin muutos aiheuttaa sen, että aikakausista on vaikea puhua. Vaikka perinteisesti käytämme tietyistä ajanjaksoista murrosajan nimitystä, tarkempi tarkastelu paljastaa, että koko tunnettu historia voitaisiin leimata murrosajaksi näkökulmasta riippuen. (Vrt. Pohjola-Vilkuna 1995, 31-32.) Esimerkiksi menuetti on historiansa aikana toisaalta voimakkaasti seurannut laajempaa yhteiskunnallista kehitystä mutta toisaalta elänyt milteipä täysin omaa elämäänsä muusta kehityksestä riippumatta. Näin kävi vaikkapa 1800-luvun alun Suomessa, jossa menuetin suosio ja vaiheet vaihtelivat erittäin voimakkaasti eri seuduilla. Menuetin ja sen

\footnotetext{
${ }^{2}$ Hyvä esimerkki tästä on menuettia käsittelevä historiankirjoitus, joka on rakennettu tietyllä tendenssillä kuten koko tanssikin. Menuetti on ollut erojen ja erottautumisen ruumiillistuma, ja sen historiaakin on kirjoitettu tässä hengessä: tarkoituksena on ollut tuoda esille ylempien piirien erottautumista rahvaasta. Kuitenkin vaikka menuetti on kokenut myös toisenlaisia vaiheita, tanssihistoria korostaa nimenomaan sen yläluokkaisia piirteitä, joten diskurssi on irtaantunut tässä tanssin todellisuudesta. Historia on näin valjastettu yhteiskuntaluokkien vä lisen erottautumisen välineeksi. (Vrt. Bourdieu 1984, 18-19.).

${ }^{3}$ Nämä argumentit ovat jossain määrin vastakkaisia aiempien tutkijoiden kuten em. Spencerin mutta myös Frances Rustin ja Anca Giurchescun kanssa. Rust $(1969,1-4)$ lähtee siitä, että sosiaalinen tanssi heijastaa aikakautensa yhteiskunnallista "henkeä" hyvin uskollisesti. Hänen mukaansa keskeistä tutkimuksessa on selvittää tanssin funktiota, joka strukturalistis- funktionalistisen tradition mukaan pyrkii säilyttämään sosiaalista integraatiota tai joissain tilanteissa vaikuttaa yhteiskunnan rakenteeseen hajottavista (ns. dysfunktiot) (mt. 25). Tämänkaltaisen ajattelun vahvana puolena on kontekstin sitominen vahvasti ilmiöön, mutta pidemmälle vietynä se sortuu kehäpäättelyyn, joka ei sinänsä kerro mitään uutta itse tanssista. Giurchescun $(1985,10-13)$ tanssidiskurssikäsite ja siihen nojautuva tarkastelutapa laajentaa näkökulmaa, mutta hänkään ei pysty irrottautumaan jäykästä rakenneajattelusta. Hän näkee yhteisöt ja näiden kulttuurit irrallisina kokonaisuuksina, jotka pyrkivät sulauttamaan vieraat elementit omien funktionaalisten sääntöjensä mukaisiksi. Yhteisöä koossa pitävien voimien heiketessä perinteinen tanssidiskurssi hajoaa, ja tanssi muuttuu sen kannalta dysfunktionaaliseksi. Pohjimiltaan Giurchescu siis nojautuu varsin pitkälle Rustin kanssa samaan traditioon.
} 
yhteiskunnallisen kontekstin välinen suhde on aina ollut monimutkainen, ja yksinkertaiset, esim. funktionalistiset tai symbolistiset selitysmallit, jotka pyrkivät ilmiön "totaaliseen" selittämiseen, eivät tavoita sen olennaisia piirteitä. On voitava hyväksyä, että tietyt piirteet tanssissa jäävät aina rationaalisen päättelyn ulkopuolelle. Ihmiselämän monimuotoisuus vaatii monimuotoista tarkastelutapaa, ja siihen pyrin omassa työssäni.

\section{"Tanssia harjoittavat ruumiit" - teoreettinen näkökulma}

\section{Tanssin ruumiillinen perusta}

Ruumiillisuus on sosiaalisesti rakentuvan todellisuuden lähtökohta. Usein puhuttaessa tämän todellisuuden ilmenemismuodoista, erityisesti kulttuurista, keskustelu siirtyy varsin abstraktille ja symboliselle tasolle. Kuitenkin M.E.Combs-Schillingin (1989, 26-27) mukaan kulttuuri uusinnetaan ruumiillisuuden kautta aivan yhtä paljon kuin mielen kategorioiden kautta. Itse asiassa ruumis tuottaa nämä kategoriat, ja mieltä "sielua" - ei voi erottaa ruumiista erillään olevaksi kokonaisuudeksi. Kulttuuri itsellään ei ole mikään monoliittinen, muuttumaton kokonaisuus, vaan se koostuu representaatioiden repertoaarista, joka on jatkuvasti enemmän tai vähemmän muutoksen kourissa. ${ }^{4}$

Tanssi on ruumiillisuudessaan keskeinen elementti yhteiskunnassa. Se on kuitenkin jäänyt varsin vähälle huomiolle tutkimuksessa juuri sen "lihallisen" luonteen vuoksi: sitä on vaikea pukea sanoiksi, koska se on ennen kaikkea liikettä ja kosketusta, nonverbaalia kommunikaatiota (Ward 1993, 18-19; Hanna 1979, 76-82), vaikkakin kommunikaatio antaa hieman väärän kuvan sen luonteesta (Parviainen 1994, 75). Länsimainen tiede on perinteisesti välttänyt ruumiillisuutta osana ihmisen kokemusmaailmaa. Ruumis on kartesiolaisen sielu-ruumis -dualismin seurauksena objektivoitu ja erotettu ihmisestä itsestään. Tiedollisuuden ylikorostaminen on johtanut siihen, että lähes kaikki sen ulkopuolelle jäävä on patologisoitu: ruumiistamme on tehty tiedostamattomien voimien temmellyskenttä, jota "varsinaisen minän" tulisi pyrkiä hallitsemaan. (Vrt. Varto 1996, 40-42; Parviainen 1994, 40-41.) Kuitenkin sekin osa kokemusta, joka on tiedollisuuden ulkopuolella, kuuluu erottamattomasti ihmisen kokonaisuuteen.

Tanssin kautta välittyneet ruumiilliset kokemukset ovat olleet tärkeitä erityisesti pohjoismaisessa luterilaisessa kulttuuri-ilmastossa. Tanssi ja leikit olivat vielä viime vuosisadalla yöjalassa käynnin lisäksi lähes ainoita hyväksyttäviä tapoja, joilla nuoret saattoivat päästä kosketuksiin vastakkaista sukupuolta olevien kanssa (vrt. Royce 1977, 199). Näitä kokemuksia on vaikea ilmaista sanallisesti, mutta on selvä, että esimerkiksi useita päiviä kestäneet häät myöhään yöhön jatkuvine tansseineen jättivät jälkensä yhteiskunnalliseen todellisuuteen. Tanssi inhimillisenä liikkeenä ja toimintana ei siis ole pelkästään yhteiskunnallisen todellisuuden heijastaja vaan olennainen osa sitä, sen

\footnotetext{
${ }^{4}$ Itse asiassa koko kulttuurin käsite on varsin epämääräinen. Ennemmin kuin kulttuurista olisi parempi puhua kulttuurisista representaatioista, jotka liittyvät toisiinsa inhimillisessä todellisuudessa. Combs-Schilling $(1989,27)$ käsittää vielä em. varauksista huolimatta kulttuurit kokonaisuuksiksi, koska hän puhuu osallistumisesta useampaan kulttuuriin sekä kulttuureiden perustasta. Aivan yhtä hyvin voitaisiin puhua representaatioiden repertoaarin laajentamisesta ja kulttuurisesti perustavista representaatioista, jolloin ei enää sitouduta yh tenäisen kulttuurin ajatukseen. Lila Abu-Lughod (1991, 144-145) onkin kritisoinut antro pologeja kulttuurin ajatuksen vaalimisesta siksi, että sen avulla perustellaan erot "meidän ja muiden" välillä. Vaikka nykyään hyväksytäänkin ajatus kulttuurien moninaisuudesta ja muuttumisesta, kulttuurin käsite säilyy erottelujen perustana.
} 
välittäjä, muokkaaja ja luoja.

Ruumiin kautta koettavat aika ja tila ovat todellisuutemme keskeiset kategoriat. Henning Eichberg (1987, 30-32) on tarkastellut länsimaisen yhteiskunnan ruumiillisten kokemusten muutoksia keskiajan lopulta nykyaikaan asti ja havainnut, kuinka mm. liikunta ja tanssi toisaalta heijastavat ja samalla tuottavat ajan ja tilan kategorioita. Tutkimuskohteeni kannalta on kiinnostavaa hänen näkemyksensä tanssista 1700-luvun aateliskulttuurissa ja toisaalta teollistumisen alkuaikoina. Hänen mukaansa 1600luvulta lähtien tanssissa suosittiin kurinalaisuutta, joka tuli esiin koreografian ankarassa geometrisuudessa ja tempon tasaisuudessa. Eichbergin mukaan (mt. 69-70) tanssin päämääränä oli täyttää (ja samalla konstruoida!) hovikulttuurin normit: hienous, täydellisyys, kohteliaisuus, sirous, säännönmukaisuus, säädyllisyys, suhteellisuus. Tanssijan ruumis oli geometrisoitu samalla tavoin kuin koko yhteiskunta aina teollisuutta ja kaupankäyntiä myöten. Myös Susan McClary (1993, 5-6) on tuonut esille tanssin merkitystä 1600-luvun aateliston ruumiiden ja käyttäytymisen säätelijänä ja synkronisoijana: Robert Isherwoodia lainaten hän korostaa sitä, kuinka tanssi ja musiikki olivat hienovaraisia keinoja harjoittaa poliittista kontrollia tanssitilaisuuksien äärimmilleen viedyn rituaalisen liikehdinnän ja tapakulttuurin kautta. ${ }^{5}$

Tanssi on siis voinut toimia poliittisen vallan välineenä, mutta toisaalta se on myös herättänyt voimakasta vastustusta, koska se kytkeytyy läheisesti seksuaalisuuteen: seksuaalisuus on olennainen osa ruumiillisuutta ja on siten varsin lähellä tanssia (Hanna 1988, 13), vaikka tanssia ei voikaan alistaa pelkäksi seksuaalisuuden osaalueeksi. Tanssin aistillisuus on pelottanut varsinkin kirkollisia piirejä keskiajalta alkaen, ja sitä on pyritty monella tapaa kontrolloimaan: tanssi pyrittiin Suomessa vielä viime vuosisadalla rajaamaan tiettyihin tilaisuuksiin, esimerkiksi häihin, joissa se on tapahtunut vanhempien ja papin valvovien silmien alla. Sen sijaan nuorison vapaamuotoiset tanssitilaisuudet, nurkkatanssit, olivat jatkuvan vainon kohteena. Ihmisruumis ja siihen liittyvä seksuaalisuus on nähty niin pelottavina, että jopa rangaistusten uhalla pyrittiin rajoittamaan tanssitilaisuuksia (Sarmela 1969, 224-226). Toisaalta halu säädellä tanssitilaisuuksia on liittynyt myös aiemmin mainittuun pyrkimykseen käyttää tanssia vallan välineenä: häissä toisaalta kirkko ja toisaalta perhe, suku ja kyläyhteisö ovat voineet osoittaa asemansa tanssin avulla.

Halu kontrolloida tanssia ja käyttää sitä manipulaation välineenä liittyy tanssin läheiseen kytkeytymiseen ruumilllisuuteen, joka toimii symbolien lähteenä. Symbolit käsitetään usein abstrakteina kokonaisuuksina, jotka toimivat ajattelun perustana ja vaikuttavat sitä kautta käyttäytymiseen. Combs-Schilling (1989, 37-39) näkee asian kuitenkin juuri päinvastaisena: ajattelun ja samalla symbolien pohja on ruumiissa. Ihmisten käsitteellisten järjestelmien ydin perustuu havaintoihin, ruumiin liikkeisiin sekä fyysiseen ja sosiaaliseen kokemukseen. Symbolien muodostuminen tapahtuu mielikuvituksen avulla, jolloin ajattelu voi irtaantua suorasta ulkoisen todellisuuden heijastamisesta. Mielikuvitus mahdollistaa "abstraktin" ajattelun, mutta senkin perustana on kokemus, joka on usein ruumiillista. Tanssissa symboliikka on moneen muuhun ilmaisumuotoon, esimerkiksi kieleen, verrattuna lähellä ruumiillista perustaa, joten se toimii monia aistikanavia hyödyntävänä varsin tehokkaana ja samalla usein pelottavana

\footnotetext{
${ }^{5}$ Michel Foucault (1980, 155-157) on todennut, kuinka 1600- ja 1700-luvuilla kurinpidosta tuli yleinen keino yliotteen saamikseksi. Ruumiiseen pyrittiin vaikuttamaan liikkeiden, eleiden, asentoje ja nopeuden tasolla. Olennaista oli ajan, tilan ja liikkeiden kodifioiminen hyvin kiinteästi. Esimerkkinä hän mainitsee sotilaallisten harjoitusten muuttumisen mekaanisiksi, pikkutarkoiksi suorituksiksi, joiden lopputuloksena alokkaasta on "talonpoika on karkotettu" ja hänestä on tehty "sotilaan näköinen".
} 
symboliikan välineenä. Sen kautta välittyy informaatiota samanaikaisesti usealla eri tavalla: visuaalisesti havaittavana tanssina, pukeutumisena ja naamioitumisena, musiikin ja muiden efektien tuottamana auditiivisena esityksenä sekä tanssijan ruumiin hajun ja lämmön aistimisena. (Royce 1977, 162-163.)

Tanssin symboliset merkitykset liittyvät usein ruumiillisuuteen ja seksuaalisuuteen, jolloin symboliikka toimii varsin konkreettisella tasolla. Tällöin tanssissa viitataan suoraan esimerkiksi miehen ja naisen väliseen kanssakäymiseen, joskus jopa sukupuoliyhdyntään. ${ }^{6}$ Suomalaisia esimerkkejä viimeksi mainitusta on useita: tässä mainittakoon Ulvilasta tallennettu tanssi Tupsunjuureen (SKS Harju, 2935), jossa sekä tanssin että laulun sanojen kautta viitataan varsin suorasukaisesti miehen ja naisen väliseen kanssakäymiseen. ${ }^{7}$ Tanssi voi myös itsellään osoittaa sukupuolten välistä eriarvoisuutta vaikkapa 1800-luvun alussa yleistyneessä länsimaisessa tanssiotteessa, joka korostaa porvarillisten ihanteiden mukaisesti miehen johtavaa roolia: nainen "lepää" miehen otteessa, ja mies määrää tanssimisen kulun. Tämä symboliikka on luonnollisesti heikentynyt yhteiskunnan miesten ja naisten välisten suhteiden muuttuessa, mutta ruumiillisuuden voima ei välttämättä katoa vaikka merkitykset muuttuisivat, joten ote on edelleen käytetyin kontaktitapa länsimaisessa paritanssissa.

Tanssi voi kuitenkin olla myös abstraktina vallan, voiman ja politiikan symbolina (Hanna 1979, 128-129). Tällöin niiden käyttöön liittyy myös tätä symboliikkaa hyödyntävän ja muokkaavan diskurssin käyttö. ${ }^{8}$ Aiemmin käsittelin jo muutamia tällaisia tapauksia, mutta tässä yhteydessä mainitsen myös kansallisuusajattelun myötä syntyneet kansantanssit, jotka ovat saaneet kansallisen symbolin aseman monissa maissa. Roderyk Lange $(1976,40-41)$ on tutkinut kujawiak-tanssia, jonka Puolan kaupunkiväestö ja maalaisaatelisto omaksuivat käyttöönsä kansallistanssina, kun se alun perin oli yksi Kujavian alueen talonpoikaisyhteisön tansseista. Uusien käyttäjien antaessa tanssille uusia symbolisia merkityksiä, myös sen koreografia muuttui. Vastaavalla tavalla suomenruotsalaisella alueella menuetti on omaksuttu yhdeksi alueen symboleista, vaikka se on ollut varsin paikallinen tanssi hyvin pitkään. Myös menuetin kohdalla tapahtui vuosisadan alussa koreografisia muutoksia, kun sivistyneistö omaksui sen käyttöönsä "Oravaisten menuetin" nimellä (ks. Heikel 1938, 460). Kummassakin tapauksessa uuden symboliikan liittäminen tanssiin edellytti siis muutosta varsinaisessa tanssissa: symbolien perusta on ruumiillisuudessa, jonka kautta muutoksen piti tapahtua, jotta uusi symboliikka saavutti hyväksynnän. ${ }^{9}$

Vahvasta symbolisesta voimastaan huolimatta tanssia ei kuitenkaan voi selittää

\footnotetext{
${ }^{6}$ Judith L. Hanna $(1979,41)$ kutsuu tätä symboliikan muotoa konkretisaatioksi, koska siinä tuotetaan asian, tapahtuman tai olosuhteen ulkoinen olemus.

${ }^{7}$ Tanssin säestyksenä käytetyn laulun sanat ovat: "Tupsunjuuree, tupsunjuuree erestä ja takkaa. Ensi reidet renkutettaa, sitte se kulli seisotettaa, sitten se pannaa pilipilipehvaan, seis, seis." Tanssissa keskeistä on lantion heiluttaminen sivulta sivulle ja lopuksi vastakkain sekä eroottisesti vihjaileva käsien käyttö lantion seudulla.

${ }^{8}$ Diskurssit kuuluvat ajattelun piiriin, ja niidenkin pohja on ruumilllisessa ja sosiaalisessa kokemuksessa. Tanssiin liittyy aina diskursseja. Ne voivat olla yksinkertaisimmillaan yrityksiä muuttaa liike sanaksi: tanssiohjeet ovat tanssiin liittyvien diskurssien ilmentymiä. Tällöin ne ovat lähellä ilmiötä, vaikkeivät tavoitakaan sitä koskaan täydellisesti. Usein diskurssit voivat kuitenkin etääntyä tanssimisesta ja tanssitilanteista, jotka vaikuttavat tällöin niiden muodostu miseen yhä vähemmän: olennaiseksi nousevat silloin sosiaalinen ympäristö ja sen erilaiset intressipiirit, ja päämääränä on tällöin tanssiin vaikuttaminen. Tanssihistoriankirjoitus on esimerkkinä tästä.

${ }^{9}$ Kujawiak muuttui yksinkertaisemmaksi ja tyylitellymäksi siirtyessään sivistyneistön käyttöön. Erityisesti sen rytminen rakenne yksinkertaistui. (Lange 1974, 40.) Myös menuetin kohdalla merkittävin muutos oli tanssin askelrytmin muuttaminen yksinkertaisemmaksi (Heikel 1938, 460).
} 
pelkästään symbolisena käyttäytymisenä; tanssi sisältää symboliikkaa, mutta lisäksi ja ennen kaikkea -se on liikettä, toimintaa ja kosketusta, jolla on muitakin kuin symbolisia merkityksiä. Ensinnäkin tanssissa korostuu Seppo Knuuttilan $(1994,149)$ ajatus siitä, että toiminta sinänsä on jo itsensä merkitys. Tanssiminen on sellaisenaan merkityksellistä toimintaa, eikä sitä voi tässä suhteessa redusoida joihinkin sen ulkopuolisiin tekijöihin. ${ }^{10}$ Lisäksi tanssiin liittyy fyysisen rasituksen, toisen ihmisen kosketuksen ja lämmön sekä ylipäätään aistillisuuden kokemista. Vaikka näiden merkityksiä on hyvin vaikea tai jopa mahdoton ilmaista, ne ovat erittäin olennainen osa tanssin ruumiillista perustaa. Niiden selittäminen pelkästään osana tanssin symboliikkaa tekisi tanssista vain yhden kommunikaatiomuodon, mitä se ei kuitenkaan kaikessa suhteessa ole. Tanssin merkitysten analysointi on ylipäätäänkin vaikeaa, koska kyse ei ole perinteisen semioottisen käsityksen mukaisista selkeistä merkkien ja merkitysten järjestelmistä, vaan merkitysten virrasta, jonka tutkiminen vaatii ilmiön kiinnittämistä kontekstiinsa ja historiaan (vrt. Bloch 1986, 10-11).

Tarkasteltaessa tanssin symbolisia ja muita merkityksiä käy ilmi, että käytettäessä tanssia vallan tai manipulaation välineenä tai haluttaessa muuten kontrolloida tanssia siihen liittyvän symboliikan määrä kasvaa ja se muuttuu abstraktimmaksi. Tällöin tanssia etäännytetään ruumiillisesta kokemisesta ja siitä pyritään tekemään mahdollisimman pitkälle ennalta määrätty. Juha Varto $(1996,64-65)$ on käsitellyt aihetta taidetanssia koskevassa kirjoituksessaan. Hänen mukaansa symbolisuus estää tanssin välittömän kokemisen, koska symbolinen ei ole koskaan koettua, vaan se on tulkittua tai tiedettyä. Varto jatkaa edelleen, että symbolisesta luopuminen vapauttaa tanssijan antautumaan omistettavaksi sukupuolisena. Nurkkatanssien, discojen tai lavatanssien tanssimista voidaankin tarkastella juuri sukupuolisen presentaation ja ruumiillisen kokemisen valossa: symbolinen sukupuoli on siellä asetettu syrjään, ja tanssija voi heittäytyä tanssiin koko ruumiillaan. Näin polarisoituneena ei tanssin kenttää kuitenkaan voi esittää: tanssi ei ole koskaan puhtaasti tiettyä tyyppiä tanssijoille tai katsojille. Merkitykset vaihtelevat tilanteiden ja toimijoiden mukaan. Se, mikä itse tanssijoille on välitöntä sukupuolista kokemista, voi toiselle katsojalle olla kauniin nuoren rakkauden symboli ja toiselle synnillisyyden ja irstauden ruumiillistuma.

Ruumiillisuuden tasolla tarkastelustani puuttuu vielä eräs merkittävä tekijä: tanssin ulkoinen ilmenemismuoto. Tähän liittyvät tanssin rakenne ja tyylin käsite, jotka muodostavat kiinteän kokonaisuuden mutta joita käsittelen analyyttisistä syistä erillään. Aiemmin tanssin rakennetta tarkasteltiin lähes täysin irrallaan muista näkökulmista (vrt. Royce 1977, 64-65). Kuitenkin viimeisten kahden vuosikymmenen aikana tanssin rakenneanalyysi on pystytty yhdistämään esimerkiksi symboliseen tarkasteluun, kuten edellä mainitusta Langen kujawiak-analyysistä käy ilmi. Tanssin rakenne onkin voimakkaasti sidoksissa tanssimiseen toimintana ja kokemuksena; rakenne ei ole abstrakti koreografia, jota tanssijat mekaanisesti toteuttavat, vaan ruumiiden liikettä ja suhteita ajassa ja tilassa. Tanssin rakenne voi olla muodoltaan hyvinkin yksinkertainen ja vapaa, jolloin yksilölliselle muuntelulle on paljon tilaa, tai se voi olla monimutkainen ja tarkasti määritelty, jolloin tanssijoiden liikkeiden yhtenäisyys on keskeistä. Tässä tulee esiin selvä kytkös tanssin symboliikkaan ja välittömään kokemiseen: tarkka muoto saa helposti abstrakteja symbolisia merkityksiä, kun taas vapaammassa tanssissa symboliikka on taka-alalla tai se on konkreettisempaa. Yksinkertainen muoto antaa

\footnotetext{
${ }^{10}$ Tähän suuntaan viittaa myös Hanna $(1979,38-39)$ todetessaan kuuluisassa tanssimääritelmässään, että tanssilla on "sisäsyntyistä" arvoa. Painopiste hänellä on kuitenkin tässä tanssin esteettisellä ulottuvuudella ja sen funktioilla.
} 
enemmän vapautta ruumiilliseen kokemiseen, mutta monimutkaiset vuorot ja kuviot sitovat tanssijan muiden asettamiin merkityksiin. Tosin tässäkään ei näin yksinkertainen selitysmalli päde, vaan todellisuus paljastuu tanssien muodon ja merkitystenkin suhteen huomattavasti vaikeammin hahmotettavaksi. ${ }^{11}$

Jos rakenne paljastaa sen, mitä tanssitaan, on tyylin kohdalla kyse siitä miten tanssitaan. Tyylikään ei ole mikään yhtenäinen tai yksiselitteinen kokonaisuus, vaan se on häilyvä ja sanallisesti varsin vaikeasti ilmaistavissa. Anya Peterson Royce (1977, 157) korostaa tyyliä identiteetin ilmaisijana; hänen mukaansa tyyli koostuu symboleista, muodoista sekä näiden perustana olevista arvo-orientaatioista. Hanna $(1979,245)$ puolestaan määrittelee tyylin liikkeen elementtien (tila, rytmi, dynamiikka, ruumiin käyttö) luonteenomaiseksi suoritustavaksi ja laaduksi; Goodmania lainaten hänkin korostaa tyylin merkitystä identiteetin ja erojen luojana (mt. 46). Erojen ja samankaltaisuuksien tuottaminen ei kuitenkaan ole tyylin koko sisältö, ja toisaalta tyyli ei ole niin staattinen ilmiö, kuin nämä määritelmät antavat ymmärtää. Laajempaa näkökulmaa käsitteeseen tarjoaa Hannu Saha (1996, 75), joka on kansanmusiikin tyyliä ja muuntelua käsittelevässä väitöskirjassaan määritellyt tyylin inhimillisessä käyttäytymisessä ja tämän tuotteissa olevien uusiutuvien piirteiden kokonaisuudeksi. Tyyliä määrittävinä tekijöinä Saha mainitsee sosiaalisen toiminnan kautta opitut rajoitukset ja yksilön itsensä normittamat mahdollisuudet. ${ }^{12}$ Tyypillistä muistinvaraiselle kulttuurille on hänen mielestään rakenneosien variaatio.

Sahan näkökulma tarjoaa hyvän lähtökohdan omalle tanssityylin tarkastelulleni. Sosiaalisen toiminnan kautta opittujen rajoitusten ja yksilöllisten mahdollisuuksien suhde riippuu siitä, missä määrin tanssi on kontrolloinnin ja manipuloinnin alaisena. Hovitansseissa, "hallittujen ruumiiden" tanssissa, yksilöllinen muuntelu oli vähemmässä määrin mahdollista, sillä keskeistä oli tanssin oikea suoritus; painopiste oli tyylin yhtenäisyydessä. Sen sijaan lavatansseissa, "vallattomien ruumiiden" tanssissa, tyylit vaihtelevat hyvinkin paljon tanssijasta toiseen: ainakin ne, jotka eivät ole saaneet oppiaan tanssikouluissa tai -ryhmissä, luovat varsin yksilöllistä tanssia. Hannan tapaan määrittelen tyylin liikkeen suorituksen luonteenomaisten piirteiden kokonaisuudeksi, mutta lisään siihen sen riippuvuuden ruumiillisuuden kontrolloinnin määrästä: tämä vaikuttaa siihen, missä määrin tyyli sisältää muutosta ja yksilöllisyyttä.

Seuraavassa esitän ajatukseni tanssin ruumiillisesta tasosta koottuna yhteen ideaalityyppiseksi konstruktioksi kuviossa 1 . On selvää, että tanssi ei ole koskaan pelkästään vallatonta tai hallittua vaan aina jotain "siltä väliltä". Tämä kuvio ei missään tapauksessa pyrikään esittämään ruumiillisuuden rakenteita sellaisina, kuin ne esiintyvät todellisuudessa. Oman työni hahmottamisen kannalta malli kuitenkin puolustaa paikkansa: siitä käy ilmi ruumiillisuuteemme liittyvä, perustavaa laatua oleva dikotomia.

\footnotetext{
11 "Yksinkertaisuus" ja "monimutkaisuus" eivät ole tarkemmassa rakenneanalyysissä yleispäteviä määreitä tarkasteltaessa ruumiillisuutta ja sen merkityksiä. Liikesarjat voivat nimittäin epämuodollisessa tanssissa olla hyvinkin monimutkaisia kuten unkarilaisissa miesten tansseissa ja muodollisissa tansseissa vastaavasti erittäin yksinkertaisia kuten viime vuosisadan katrilleissa. Vasta yhteiskunnallinen ja historiallinen kontekstualisointi auttavat selittämään tarkemmin rakenteen eri piirteitä.

12 Sahan $(1996,75)$ mukaan tyyli voidaan tunnistaa tuotteista mutta selittää vain tekoprosesseista, musisoinnista, eli hänenkin lähtökohtanaan on inhimillinen toiminta.
} 


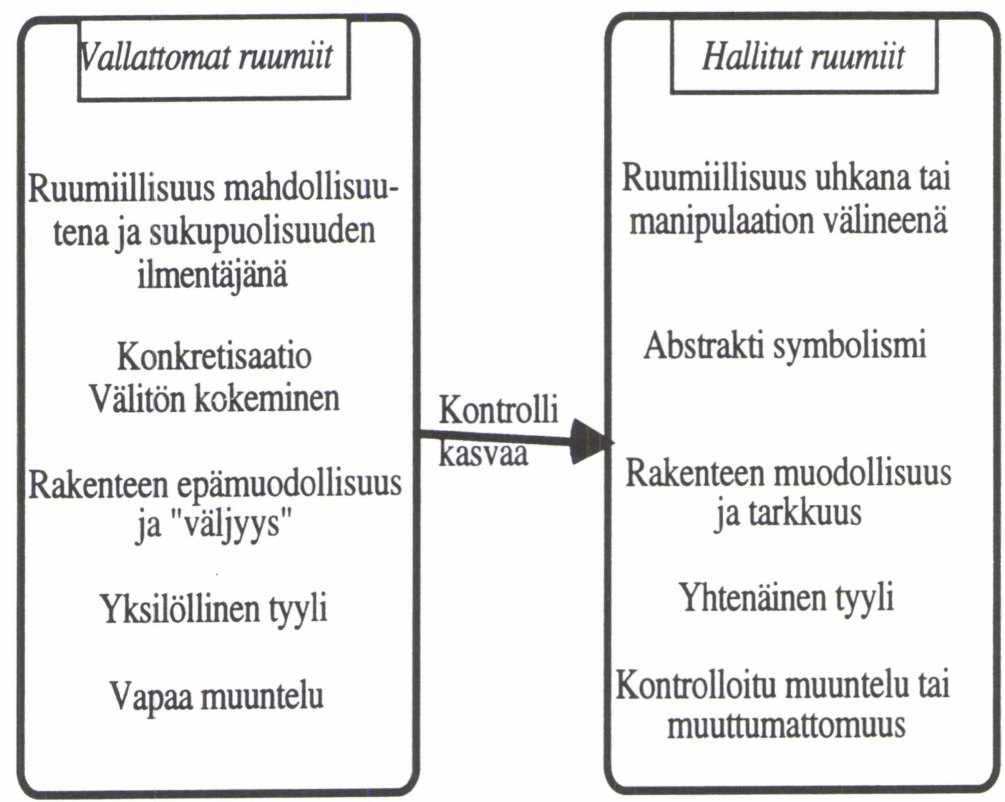

Kuvio 1. Ruumiillisuuden taso.

\section{Sosiaalinen konteksti}

Tanssin välittömin konteksti on tanssitilanne. Yksittäinen tanssi ei ole itsenäinen kokonaisuus, vaan sen merkitykset määräytyvät suhteessa tilanteeseen ja muihin tansseihin. ${ }^{13}$ Tanssi ja tanssitilanne ovat sosiaalisesti rakentuneita, ja niiden takana on inhimillisen toiminnan taipumus kaavamaistua (Berger \& Luckmann 1987, 70). ${ }^{14}$ Kaavamaistuminen ja sitä seuraava institutionaalistuminen ${ }^{15}$ ovat seurausta toimijoiden ruumiillisesta kokemuksesta, jonka he kokevat olevan objektiivisen todellisuuden heijastaja; siksi tanssitilanne koetaan ennalta määrättyjen sääntöjen alaiseksi, vaikka "säännöt" ovatkin viime kädessä inhimillistä toimintaa ja sellaisina muuttuvia. ${ }^{16}$

\footnotetext{
${ }^{13}$ Giurchescu $(1987,10)$ kutsuu tanssitilanteen tanssien muodostamaa ja sen semanttisista ja syntaktisista ulottuvuuksista riippuvaa kokonaisuutta tanssidiskurssiksi. Hänen mukaansa tilaisuuden rakentuminen riippuu kulttuurisista säännöistä, joiden analysointi on hänen tarkastelussaan keskeistä. Analyysi jää kuitenkin varsin formaalille tasolle eikä siinä oteta tarpeeksi syvällisesti huomioon tilanteen kiinnittymistä historiaan.

${ }^{14}$ Kun jotain toimintaa toistetaan usein, siitä muodostuu malli, joka voidaan toistaa mahdollisimman vähällä vaivalla. Ihminen vapautuu jatkuvasta päätöksenteosta, kun suurin osa toiminnasta muuttuu rutiineiksi. (Berger \& Luckmann 1987, 70-71.).

${ }^{15}$ Instituutioilla tarkoitetaan tapojen ja mallien kokonaisuutta, joka on tietyn ryhmän kaikkien jäsenten käytettävissä (Berger \& Luckmann 1987, 71).

${ }^{16}$ Peter L. Bergerin ja Thomas Luckmannin $(1987,72)$ mukaan instituutioilla on oma historiansa, joka ulottuu pidemmälle kuin yksilön historia, ja instituutiot asettavat ennalta määrättyjä kaavoja ihmisen toiminnalle. Historiallisuuden korostaminen onkin erittäin tärkeää, koska vain sen kautta instituutioita pystytään selittämään ja ymmärtämään. Berger ja Luckmann eivät tuo kuitenkaan tuo esille tarpeeksi selkeästi sitä, että "kaavat" eivät suinkaan välity ihmiseltä toiselle ikään kuin tietokoneohjelmina vaan ne opitaan havaintojen ja kokemusten kautta, vaikka tämä ajatus sisältyykin implisiittisesti heidän kirjoituk-
} 
Tanssitilanne ei kuitenkaan ole autonominen yksikkö, vaan se on jatkuvassa vuorovaikutuksessa yhteiskunnan muiden sektorien kanssa. Mikä on sitten tanssitilanteessa erikoista suhteessa muuhun yhteiskuntaan?

Monet tutkijat ovat tarkastelleet tanssia rituaalisen käyttäytymisen muotona. Joann W. Kealiinohomokun $(1997,67)$ mukaan tanssi on osa rituaalista käyttäytymistä, joka eroaa arkitodellisuudesta: normaalisti ihmiset kävelevät ja puhuvat, mutta arkitodellisuudesta irroitetuissa tilanteissa he tanssivat ja laulavat. Rituaali nähdään tässä nimenomaan toistuvana käyttäytymismuotona, joka poikkeaa jokapäiväisestä elämästä. Tätä poikkeamista on käsitellyt Victor Turner (1969, 94-97), joka on siirtymäriittejä tarkastellessaan jakanut ne Arnold van Gennepin tavoin kolmeen vaiheeseen: ero, kynnys ja uudelleen kiinnittyminen. Olennaisin vaihe tässä on kynnys (lat. limen), jossa subjekti ei kuulu edelliseen eikä tulevaan tilaan vaan on siinä "välissä". Tässä tilassa ilmenee sosiaalisen järjestyksen (Turnerin sanoin struktuurin) vastakohtana communitas: strukturoimaton yhteisyys ja homogeenisyys. Turnerin ajatuksia liminaalisuudesta voidaan tietyltä osin soveltaa myös tanssiin, sillä tanssi on usein marginaalinen ilmiö, joka muodostaa vastakohdan jokapäiväisen elämän kanssa. Siinä ihmiset irtaantuvat rutiineistaan ja normaalista sosiaalisesta järjestyksestä. (Spencer 1985, 28.) Joissain tanssitilanteissa saattaa sosiaalinen järjestys purkautua siinä määrin, että voidaan puhua communitaksesta, mutta useimmiten tanssitilanteessa järjestys korvautuu toisella, joka voi olla vastakohta normaalille järjestykselle tai sen kristallisoituma, ideaali.

Turnerilaisen ajattelun puutteena on se, että siinä rituaalin merkitykset eivät liity sen fyysisiin muotoihin mitenkään kiintäesti vaan niitä tarkastellaan erillisinä. Rituaalin muotoja ei kuitenkaan voi erottaa sen merkityksistä. Stanley J. Tambiah $(1985,132)$ toteaa, että rituaalien muodolliset piirteet, toisto, tyylittely, järjestely, esitystyyli sekä esille asettelu ovat olennainen osa rituaalin kokemista. Rytminen toistuvuus legitimoi ja tuo pysyvyyttä rituaalien sosiaalisesti rakentuneisiin toimintoihin. ${ }^{17}$ Muoto on siis erittäin keskeisessä asemassa rituaalisessa kokonaisuudessa: muodon systematiikka on olennainen sen pohjalle rakentuvan merkityksen kannalta (Combs-Schilling 1989, 29). Tätä taustaa vasten tanssin ruumiillisuus ja rytmisyys tekevät siitä tärkeän osan rituaalista käyttäytymistä. Fyysinen muoto ja abstrakti ajattelu ovat jatkuvassa vuorovaikutuksessa keskenään (mt. 46), ja tanssissa muoto saa voimakkaan ruumiillisen ilmaisun, joka aiemmin mainitulla tavalla toimii symboliikan lähteenä.

Ajatus tanssista rituaalisena käyttäytymisenä pohjautuu siis kahteen seikkaan: tanssi voidaan nähdä normaalista poikkeavana ja omaan todellisuuteensa sijoittuvana toimintana, johon voi liittyä myös communitas-ajattelua, sekä rytmisenä ja toistuvana ruumiillisen ilmaisun muotona, joka toimii katalyyttinä symboliselle ajattelulle. Kuitenkaan tanssitilaisuuksia ei voi käsitellä yhden ja saman rituaalin "variaatioina", vaan ne poikkeavat toisistaan selvästi: rituaaliset ainekset vaihtelevat niissä tanssin

siinsa. Korostan itse erityisen voimakkaasti sitä, että nämä "kaavat" elävät toiminnassa eivätkä jossain "mielen kategorioissa". Tästä syystä ne ovat jatkuvan muutoksen alaisia.

${ }^{17}$ Kealiinohomoku $(1997,69-70)$ näkee rituaalin usein pyrkimyksenä todellisuuden epävarmuuksien hallintaan. Elämään kuuluu paitsi syntymistä ja rakentamista myös kuolemaa ja tuhoutumista; jälkimmäistä ei välttämättä nähdä pahana, vain pelottavana ja sellaisena, johon pitää ulottaa kontrolli. Rituaali toimii juuri tällaisena välineenä. Combs-Schillingin $(1989,29)$ mukaan ritualisoituneiden toimintojen säännöllinen toistuminen on tärkeää sekä yksilölle, yh teisölle että näiden määrittelemälle maailmalle. Rituaalit luovat turvallisuutta ja varmuutta an taen elämälle ja maailmalle merkitystä. Lisäksi hän toteaa ihmisten kokevan rituaalit parhaim millaan syvällisimpänä ja olennaisimpana elämänä; tällöin rituaali ja sen osallistujat muuttuvat tosioleviksi, kun taas kaikki muu on epätodellista. 
askelkuvioiden ja tanssimaneereiden toistosta laajamittaisiin uskonnollisiin riitteihin tai poliittisiin seremonioihin. Tanssitilaisuuksia voikin tarkastella siltä kannalta, miten rituaalinomaiset piirteet niissä ilmenevät. Tätä tarkoitusta varten on tarpeellista palata ruumiillisuuden, merkitysten ja symbolien välisiin suhteisiin.

Aiemmin totesin, kuinka tanssia voidaan käyttää vallan tai manipulaation välineenä abstraktia symboliikkaa hyväksi käyttäen. Sen sijaan tanssin ollessa epämuodollisempaa siihen liittyvä symboliikka on konkreettisempaa ja ruumiillisuuden välitön kokeminen nousee keskeiseksi. Näiden kahden ideaalityypin kontekstina voidaan pitää, Timo Leisiön (1992, 10-11) termejä käyttäen, seremoniallista tanssitilannetta ja toisaalta juhlintaa. ${ }^{18}$ Leisiö määrittelee seremonian sosiaalista valtaa symboloivaksi rituaaliksi. "Seremonia on "sosiaalinen näytelmä", jonka viestinä on valta, kilpailu tai miksei myös ristiriita." (Mt. 10.) Seremonia on "hallittujen ruumiiden" toimintakenttää, jossa ihanteena on tilanteen toteutuminen ennalta määrättyjen suunnitelmien mukaan. "Vallattomat ruumiit" sen sijaan toimivat juhlinnan puitteissa. Leisiön (mt. 11) määritelmässä "juhlinta on ritualisoitua leikkiä, tunteiden muodollista ilmaisua". ${ }^{19}$ Itse korostan kuitenkin ruumiillisuuden mahdollisuuksia juhlinnassa: juhlinta on konteksti, jossa ruumis pystyy kohtaamaan toisen ruumiin ja itsensä normaalista poikkeavalla tavalla ilman pitkälle vietyä kontrollia. Koska juhlintakin on rituaalia, on siinä tiettyjä toistuvia piirteitä, mutta niiden esiintyminen ja muoto eivät ole seremonian tavoin tarkasti ennalta määrättyjä, ja siinä tapahtuva kontrolli on väljää ja yksilöllistä muuntelua sallivaa.

Millä tavoin sitten marginaalisuus ja ruumiillisuus ilmenevät tanssitilanteen eri muodoissa? Kaikille tanssitilanteille on tyypillistä, että ne edustavat jossain määrin poikkeavaa todellisuutta. Kuitenkaan seremoniallisessa yhteydessä sosiaalinen järjestys ei muutu täysin homogeeniseksi yhteisöllisyydeksi, vaan sosiaalisten suhteiden välinen kontrolli ja hierarkkisuus säilyy, vaikkakin muuttuneena. Esimerkiksi viime vuosisadan alun länsisuomalaisissa häätansseissa oli piirteitä sekä hierarkkisuudesta että yhteisöllisyydestä: toisaalta niissä tanssin aloittajana toimi usein pappi, joka näin korotettiin yhteisön hierarkian yläpäähän, mutta toisaalta niihin saattoi liittyä seremoniallisia tansseja, miesten ja naisten "rinkejä", joihin talonpojat ja torpparit saattoivat osallistua tasavertaisesti. Nämä ringit toimivatkin siirtymäriitteinä, joissa hääpari siirtyi naimattomien säädystä aviosäätyyn.

Juhlinnassa sen sijaan vahva kontrolli ja hierarkkisuus ovat selvästi taka-alalla, vaikka tietty sosiaalinen valvonta onkin läsnä kaikissa tilanteissa. Yhteisöllisyyden esiintyminen vaihtelee myös juhlinnassa, tosin eri tavoin kuin seremonioissa. Esimerkiksi nykyaikaisissa lavatansseissa ei välttämättä synny yhteisyyden tunnetta, vaan kaikki luovat vain omaa tai korkeintaan parin kanssa yhteistä tanssia. Sen sijaan esimerkiksi rockkonsertissa saattaa vapaasti tanssiva yleisö kokea communitaksen häivähdystä, kun tiiviisti toisiinsa kiinni pakkautuneet ruumiit alkavat liikkua samaan tahtiin. Yhteisöllisyyden vastapoolina juhlinnassa ei siis ole hierarkkisuus vaan atomistisuus.

Seremoniat ja juhlinta eivät suinkaan ole toisiaan poissulkevia kategorioita, vaan

\footnotetext{
${ }^{18}$ Seremonia ja juhlinta ovat Leisiön määrittelyssä kaksi rituaalin viidestä lajista. Muut ovat oikea käytös, liturgia ja magia (Leisiö 1992, 8-11). Näillä ei kuitenkaan tässä yhteydessä ole merkitystä, koska kaksi ensiksi mainittua muodostavat oman tarkasteluni kannalta merkittävimmän vastakohtaparin.

${ }^{19}$ Rinnastus leikkiin tässä yhteydessä on mielenkiintoinen huomio, koska Johan Huizinga on kuuluisassa teoksessaan Leikkivä ihminen $(1984,17)$ määritellyt leikin ennen kaikkea vapaaksi toiminnaksi, joka luonnehtii hyvin myös tässä käytettyä juhlinnan käsitettä. Huizingan näkemyksissä leikistä on muutenkin yhtäläisyyksiä "vallattomien ruumiiden" tanssin ja juhlinnan kanssa.
} 
seremoniaan voi useinkin liittyä juhlinnan piirteitä ja päinvastoin (vrt. Leisiö 1992, 11). Pidän tätä jakoa kuitenkin mielekkäänä tarkasteluni kannalta. Ne liittävät ruumiillisen tanssin eri aspektit rituaaliseen kontekstiinsa ja toisaalta mahdollistavat kontekstualisoinnin laajentamisen muuhun yhteiskuntaan. Ruumiillisuutta käsitellessäni otin esille sen, kuinka tanssi muokkaa yhteiskunnallista todellisuutta vaikuttamalla siihen, kuinka aika ja tila koetaan: sitä kautta muodostuvat vallan ja manipulaation muodot ja kategoriat. Nyt keskityn enemmän siihen, kuinka yhteiskunnallinen konteksti vaikuttaa tanssitilaisuuteen.

Yleiset yhteiskunnalliset olosuhteet luovat kehykset tanssitilanteille ja tanssimisille. Tilanteet voivat olosuhteiden myötä joko säilyä vuosisatojen ajan lähes muuttumattomina tai muuttua vaikkapa poliittisen kuohunnan myötä hyvinkin radikaalisti. Ranskan vallankumous ja ensimmäinen maailmansota ovat esimerkkejä ajanjaksoista, joiden aikana tai jälkeen tanssit ja tanssitilanteet muuttuivat hyvinkin perusteellisesti (Rust 1969, 65, 86-87). Yhteiskunnalliset mullistukset eivät kuitenkaan vaikuta tanssimiseen deterministisesti, vaan jotkut tanssit tai tilanteet saattavat säilyä hyvinkin erilaisissa olosuhteissa, kun taas toiset muuttuvat tai katoavat ainakin näennäisesti stabiilissa yhteiskunnallisessa tilanteessa; pohjalaisen menuetin säilyminen tälle vuosisadalle on erinomainen esimerkki ensiksi mainitusta ja pavanen häviäminen 1600-luvun hovitanssirepertoaarista jälkimmäisestä. Tanssitilanteet ovat olennainen osa sosiaalisen elämän monimuotoisuutta, ja siksi hyvin monet tekijät vaikuttavat niihin eikä yhtä selitystä voida nostaa muiden yläpuolelle. Tarkastelutavasta ja tutkimusasetelmasta riippuu se, mitkä piirteet yhteiskunnallisesta kontekstista ovat kulloisessakin tilanteessa relevantteja. Seuraavaksi tarkastelen muutamia esimerkkejä, joita olen itse käyttänyt työssäni.

Valtiolliset olosuhteet eivät välttämättä vaikuta perinpohjaisesti sosiaaliseen tanssimiseen, mutta niiden luomilla yhteyksillä ja kanssakäymisellä on merkitystä. Esimerkiksi satavuotisen sodan (1337-1453) aikana ranskalaiset sotavangit toivat Englantiin todennäköisesti mannermaisen Basse Dansen sekä siihen liittyvän seremoniallisen tanssimisen (Rust 1969, 35-36). Suomen liittäminen Venäjään vuonna 1809 puolestaan vaikutti siihen, että idästä ja erityisesti Pietarista alkoi tulla uusia tansseja aina länsirannikolle asti, kun aiemmin tanssivaikutteet olivat tulleet valtaosaltaan Ruotsista; esimerkiksi Suomessa 1800-luvulla ja 1900-luvun alussa yleisen purpurin juuret ovat mahdollisesti Pietarin hovissa. Suoran vaikutuksen sijaan valtiollinen politiikka vaikuttaa enemmän kuitenkin esimerkiksi makrotason talouden kautta. Suomessa Turun rauhan (1743) seurauksena savolaisten ja keskisuomalaisten yhteys Suomenlahdelle katkesi, kun Kymijoesta tuli rajajoki. Terva- ja kaskiviljakauppa alkoi tämän jälkeen suuntautua Pohjanlahden kaupunkeihin, minkä seurauksena tanssilliset ja myös mm. uskonnolliset vaikutteet alkoivat kulkeutua yhä enemmän länsi-itä suunnassa. (Hoppu 1997, 53.)

Taloudelliset muutokset ovat muutenkin vaikuttaneet tanssiin paitsi luomalla yhteyksiä myös muuttamalla työn ja vapaa-ajan suhdetta sekä vaikuttamalla yhteiskuntarakenteeseen. Paikallisella tasolla tämä on ilmennyt esimerkiksi säätykiertona: taloudellinen vaurastuminen tarjosi 1700-luvun lopulla Munsalassa talonpojille mahdollisuuden aloittaa laajempi kaupankäynti ja siirtyä näin porvaristoon (Åkerblom 1973, 162-164). On todennäköistä, että tämä vaikutti säätyjen lähentymiseen ja sitä kautta tanssillisten vaikutteiden nopeampaan välittymiseen. Samalla alueella myös liikenneyhteyksien kehittyminen lisääntyvän laivanrakennuksen ja talonpoikaispurjehduksen myötä lisäsi erilaisten kulttuuristen vaikutteiden saapumista alueelle (mt. 164-165).

Myös tekniikan kehittyminen on muuttanut tanssimisen olosuhteita esimerkiksi 
tanssitilan suhteen: myöhäiskeskiajan Englannissa tulipesän siirtyminen keskeltä lattiaa huoneen reunalle mahdollisti uudenlaisten rivistötanssien käyttöönoton aikaisempien piiritanssien rinnalle (Rust 1969, 35). Talouden ja tekniikan vaikutus tanssiin on kuitenkin erittäin monimutkainen ja vaikeasti arvioitavissa, mutta se kytkeytyy usein ajan ja tilan hahmottamisen kysymyksiin, ja sellaisena vaikutus on molemminpuolinen.

Aatteellisiksi muutoksiksi voidaan laskea uskonnon ja aatteellisten järjestöjen toiminta. Esimerkiksi herätysliikkeet ja nuorisoseurat ovat ottaneet kantaa tanssimiseen koko olemassaolonsa ajan. Suurin osa herätysliikkeistä on vastustanut voimakkaasti kaikenlaista tanssia, ${ }^{20}$ ja nuorisoseuroille tanssiminen oli puolestaan vuosisadan vaihteessa vaikea kysymys, johon tanhuharrastus antoi yhden vastauksen (Kurkela 1989, 185-187). Herätysliikkeet vaikuttivatkin moni paikoin tanssin vähenemiseen ja muuttumiseen yhä enemmän nurkkatanssimaiseksi, "kielletyksi" toiminnaksi. Nuorisoseurojen toiminta puolestaan vaikutti juuri päinvastaiseen suuntaan: nuorison spontaanit tanssit vähenivät, ja tilalle tulivat seuraintalojen iltamien yhteydessä pidetyt tanssit sekä tanhuharjoitukset ja -esitykset, jotka kaikki olivat selvästi nurkkatansseja kontrolloidumpia tanssitilanteita.

Aatteellisen toiminnan vaikutus tanssimiseen ei kuitenkaan aina ole näin suora. Järjestöjen keskinäiset vuorovaikutussuhteet saattavat heijastua myös tanssiin. Dennis Rundt (1992, 114-115) on todennut, että munsalalainen babtistiliike valmisti tietä pitäjän myöhemmälle vasemmistoradikalismille, joka oli laajempaa kuin missään ruotsinkielisellä Pohjanmaalla. Vasemmistoradikalismin synty puolestaan kytkeytyi paikkakunnan nuorisoseurojen syntyyn, sillä samat henkilöt saattoivat olla perustaa sekä nuorisoseuran että työväenyhdistyksen ja toimia molemmissa (mt. 93-94). Munsala oli vahvaa menuettialuetta, ja nimenomaan nuorisoseuroissa sitä suosittiin voimakkaasti. On varsin todennäköistä, että paikkakunnan radikalismi vaikutti tanssin säilymiseen mutta myös muuttumiseen, sillä menuetin tavallisimmaksi muodoksi vakiintui tällä alueella raju ja nopeatempoinen hyppymenuetti.

Lähimpänä itse tanssitilannetta ovat sosiaalista vuorovaikutusta säätelevät tavat ja tottumukset. Matti Sarmela $(1969,227)$ mainitsee nuorison seurustelua ja kohtaamista käsittelevässä teoksessaan uusien sosiaalistumistapojen saapuneen Suomeen 1700luvulta lähtien aluksi Pohjanmaalle ja vähitellen muuallekin. Tälle vaiheelle oli tyypillistä nuorten ryhmien syntyminen kyläyhteisöihin (mt. 181-182). Näissä ryhmissä puolestaan tanssitaidosta kehittyi vähitellen merkittävä arvoaseman mittari. Tanssimisesta tuli nuorison merkittävin vapaa-ajanviettomuoto, ja sen seurauksena nuoret alkoivat kiinnittää huomiota ulkonäköönsä yhä enemmän. Esimerkiksi poikien keskuudessa oli nuoren aiemmin ollut tärkeä osoittaa voimaansa miehuutensa merkkinä, mutta nyt tärkeäksi nousi vaikkapa parran tai viiksien kasvattaminen. (Mt. 193.) Huomion arvoista on se, että keskeisenä osana sosiaalistumista on molemmissa tapauksissa ruumiillisuus: sen kokeminen vain muuttuu arvostuksen siirtyessä fyysisestä voimasta tanssitaitoon ja ulkonäköön.

Yhteiskunnalliset olosuhteet vahvistavat milloin tanssin muodollisia, seremoniallisia piirteitä milloin epämuodollisia, juhlinnanomaisia piirteitä. Tanssin kieltäminen tai hyljeksintä yhteiskunnan tai herätysliikkeiden taholta johtaa ensimmäisenä seremoniallisen tanssin katoamiseen, mutta epämuodolliset tanssit säilyvät piilotettuina. Näin kävi viime sotien aikana, jolloin tanssikielto oli voimassa: tanssiminen häissä ja muissa

${ }^{20}$ Poikkeuksena on kuortanelainen vasulaisten uskonnollinen liike, joka 1800-luvulla käytti rituaalista tanssia keinona päästä yhteyteen Jumalan kanssa (Klemetti 1932. 231-256). 
virallisissa tilaisuuksissa loppui, mutta nuoret järjestivät omia salaisia tanssitilaisuuksia. Sen sijaan tanssin kontrollointi johtaa - luonnollisesti - tanssitilaisuuksien seremoniallisten piirteiden kasvuun: tanssista tulee ohjelmanumero ja sitä valvotaan muuten säätelemällä tanssittavaa musiikkia tai säätelemällä tanssijoiden käytöstä esimerkiksi järjestysmiesten avulla. Taloudelliset, tekniset ja poliittiset olosuhteet luovat tanssin laajemmat puitteet, joiden vaikutus ilmiöön vaatii aina tarkkaa selvitystä kussakin tapauksessa. Tiivistettynä tanssin kontekstuaalisuus on esitetty kuviossa 2.

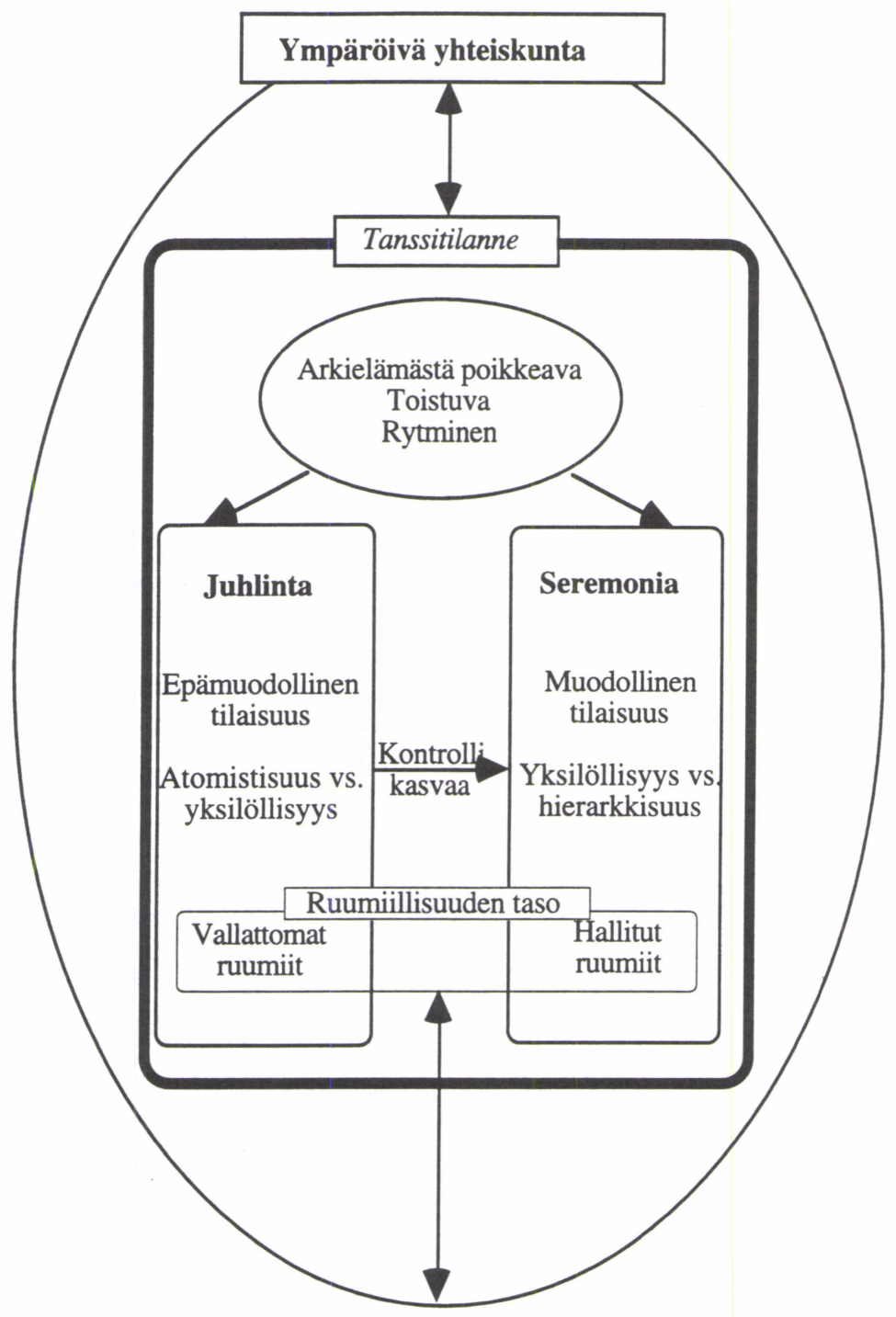

Kuvio 2. Sosiaalisen kontekstin taso.

\section{Historia}

Kontekstin synkroninen analyysi tuo esille ilmiön niitä piirteitä, jotka sillä on tietyssä ajassa ja tietyssä paikassa. Todellisuus ei kuitenkaan ole hyvin järjestynyt systeemi, 
jonka osat toimisivat saumattomasti yhdessä, vaan se sisältää aineksia eri ajoilta, ja nämä ainekset ovat aina alttiina muutokselle (vrt. Geertz 1973, 406-407). Vaikka me toimimme yleensä kuin todellisuutemme osaset olisivat itsestään selvyyksiä, objektiivisia tosiasioita, todellisuus on kuitenkin rakentunut ruumiillisen toiminnan ja sosiaalisen vuorovaikutuksen kautta. Tanssin suhteen tämä huomio on erityisen tarpeen, koska tanssi koostuu usein rakenteista ja merkityksistä, joiden "järkeä" on vaikea ymmärtää pelkästään synkronisesta näkökulmasta. Näennäisesti järjettömänkin käyttäytymisen takana on tietty historia, ja ilmiön tarkastelu kokonaisuutena vaatii myös sen historian tarkastelua.

Olen itse asiassa sivunnut historiallista näkökulmaa jo useampaan otteeseen; käyttämäni "trialektiikan" osat eivät ole toisiaan poissulkevia, vaan päällekäinen tarkastelu on väistämätöntä. Aion tässä luvussa kuitenkin tutkia historiallisuutta hieman tarkemmin ja selventää sen kytkeytymistä aiempiin näkökulmiin.

Keskeisiä kysymyksiä ovat muutos ja jatkuvuus. Muutos on tämän näkökulman ensimmäinen edellytys, koska se antaa diakroniselle tutkimusotteelle sen mielen. Siihen on voitu suhtautua eri tavoin. Presentistisessä historiantutkimuksessa menneisyys on nähty ihanteellisena olotilana, jonka muutos on hävittänyt ja jonka päättyminen voidaan määrittää tiettyyn ajankohtaan tai murrokseen. Traditionalismissa on puolestaan etsitty jatkuvuutta menneisyyden kirjosta, joka nähdään muuttuvien merkitysten ja kontekstien valossa nykyisyyden määrääjäksi. (Knuuttila 1994, 18-20.) Esimerkiksi Wigdis Jorunn Espeland (1991, 29) on tutkiessaan 1960-luvun norjalaista nuorisotanssia löytänyt siitä sekä menneen tanssin katkosta että sen jatkumista. Hänen mukaansa nuoret omaksuivat vanhoja yleisemmin "shake"-tanssin ja hylkäsivät näin aiemmat tanssimuodot. Kuitenkin nuoret myös sopeuttivat tangon rock'n'rolliin "slow"tanssina, josta tuli shaken ohella nuorison päätanssi.

Edellä mainittuihin näkökulmiin liittyy kuitenkin monia ongelmia, joita mm. Knuuttila (1994, 19-21) on käsitellyt. On toki selvää, että menneisyys on täynnä katkoksia, jolloin tietyt ilmiöt ovat hävinneet tai muuttuneet perusteellisesti, sekä jatkuvuutta, joka ilmenee traditioiden pysymisenä tai vain vähäisenä muuttumisena. Katkokset eivät kuitenkaan ole niin dramaattisia, kuin presentistit antavat ymmärtää. Alussa jo totesin, kuinka koko tunnettua historiaa voitaisiin pitää murrosaikana tarkastelukulmasta riippuen. Toisaalta jatkumojen lisäksi ilmiöihin liittyy paljon lyhytikäisiä piirteitä, kuten vaihtuvia tyylejä, muoteja ym., jotka ovat todellisuuden kannalta yhtä merkittäviä kuin pitkäikäiset traditiotkin.

Sen sijaan, että keskittyisin pelkästään katkosten ja jatkumojen tarkasteluun, kiinnitän työssäni huomion niihin olosuhteisiin, joiden puitteissa todellisuus tuotetaan ja uusinnetaan. Tanssi ilmenee historiassa omalla erityisellä tavallaan, mihin vaikuttavat erilaiset tapahtumat ja olosuhteet; siksi tanssin historiallisten ilmenemismuotojen tarkastelu paljastaa, millaisesta ilmiöstä on kyse (vrt. Bloch 1986, 11). Näkökulma ei ole tällöin staattisten rakenteiden tutkimista vaan ilmiön tarkastelua liikkeessä ja muutoksessa (mt. 183). Tanssijat toimivat ajassa ja tilassa, jotka he tuottavat ruumiillisesti mutta jotka kuitenkin ilmenevät yksilölle valmiina objektiivisena todellisuutena. Vertaamalla tanssitilanteita ja tanssin muotoja sekä niiden laajempaa kontekstia eri aikoina voidaan tunkeutua tämän objektiivisuuden läpi ja ymmärtää, miksi tietyt liikkeet, tyylit ja tanssit ovat olemassa ja mikä on niiden merkitys.

Tällainen näkökulma tuo tanssin käytön keskeiseksi, ja samalla aitouden ongelma jää syrjään. Tällaista näkökulmaa edustaa myös Knuuttila $(1994,149)$ erottaessaan käytön ja käyttötarkoituksen toisistaan: Ritvalan helkajuhlia tarkastellessaan hän toteaa juhlan käyttötarkoitusten muuttuneen useita kertoja vuosisatojen aikana, mutta sen käyttö on säilynyt omana merkityksenään häiriintymättä aitouden tai alkuperäisyyden 
epäilyksistä. Samoin esimerkiksi menuetin käyttötarkoitukset ovat muuttuneet varsin rajusti siirryttäessä barokkihoveista riihitansseihin ja sieltä puolestaan kansantanssiryhmien ohjelmistoon. Mitään näistä ei voi käytön kannalta nostaa toisia aidommaksi, sillä toimijoille tanssi on nimenomaan tanssia. Aidon ja alkuperäisyyden etsiminen on kuin sipulin kuorimista: loppujen lopuksi havaitaan, että ne monet kerrokset ovatkin se, mitä etsitään. Näin myös tanssin kerrostumat ajassa ovat itsessään merkityksellisiä ja toinen toistaan määrittäviä: aiemmat tilanteet ja muodot määrittävät myöhempiä, joiden valossa aiempia katsotaan.

Kuitenkin on huomattava, että historiakaan ei paljasta mitään "viimeistä totuutta" tanssista. Kuten olen todennut, tanssissa on aina jotain, joka pakenee rationaalisuutta, eikä sitä löydy edes vuosisatojen taakse ulottuvan tutkimuksen avulla. Silti uskon hahmottelemani trialektiikan avulla voivani luoda kuvan tanssista omana erityisenä inhimillisen todellisuuden muotona. Ennen kuin lähden tarkastelemaan menuettia tässä valossa, kokoan vielä näkökulmani kuvioon 3.

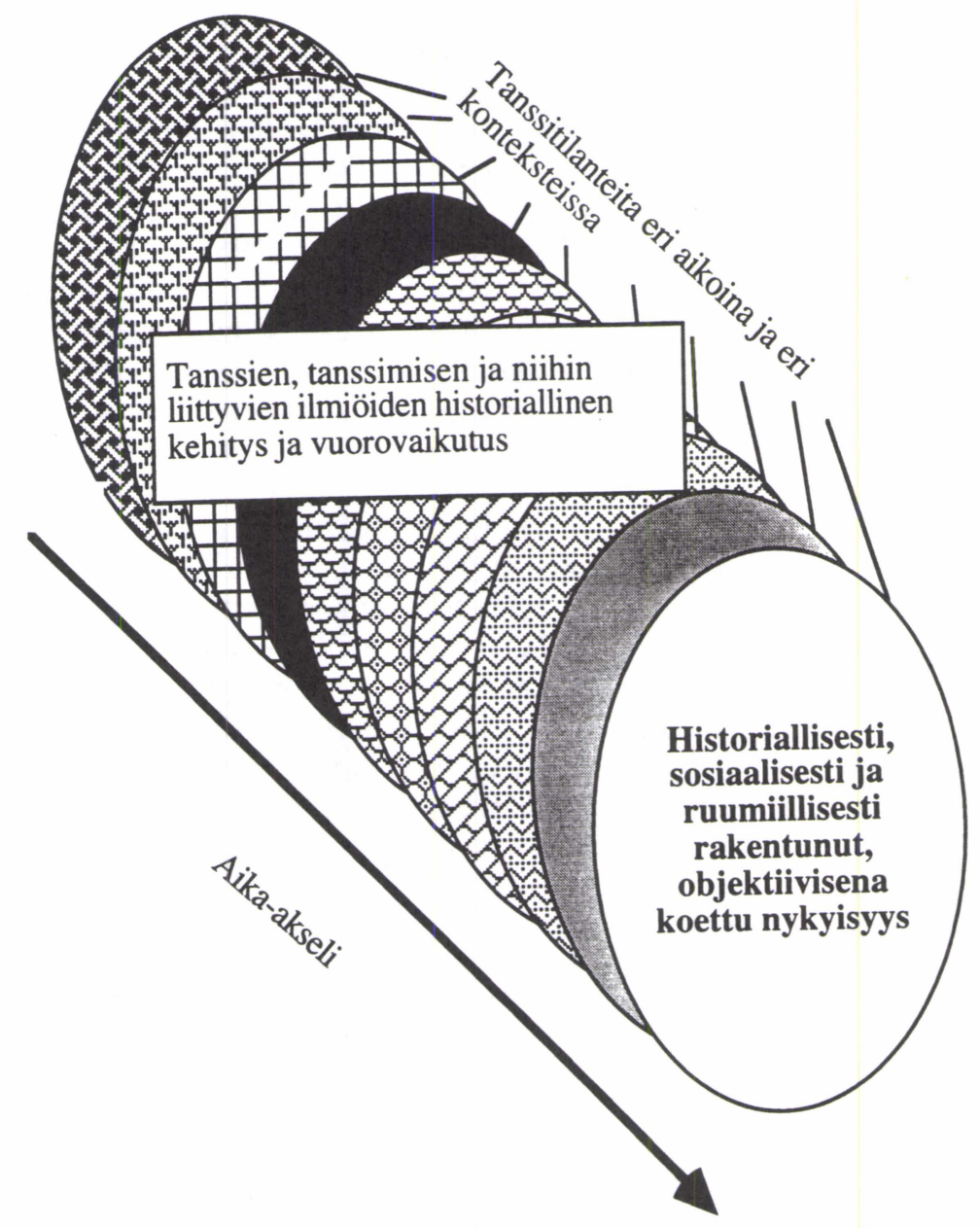

Kuvio 3. Historiallinen taso. 


\section{Gaillardesta menuettiin: hovitanssin kurinalaistaminen}

"Menuetti on tanssitaiteen sydän," todettiin weimarilaisessa lehdessä Journal des Luxus der Moden vuonna 1797 (Taubert 1988, 14). Tällöin oli kulunut lähes puolitoista vuosisataa tuon "tanssien kuningattaren" synnystä, ja Euroopassa olivat meneillään suurimmat valtiolliset mullistukset sitten kolmikymmenvuotisen sodan. Ranskan vallankumous ja sen jälkeiset sodat olivat tiputtaneet useita kruunupäitä valtaistuimiltaan. Mikään ei tuntunut pysyvältä, ei edes menuetti, ja pian oli senkin vuoro tulla suistetuksi jalustaltaan, jolle se oli nostettu aurinkokuninkaan hovissa. Kuitenkin menuetista pidettiin tiukasti kiinni, kuten mainittu lehtiartikkelin katkelma osoittaa. Muutosta ei haluttu hyväksyä, sillä kyseessä oli paljon muutakin. Menuetin koettiin olevan viimeinen side menneeseen maailmaan. Sitä tanssiessa koettiin ruumiillisesti se todellisuus, jossa kaikki oli omalla paikallaan järjestyksessä ja jota mikään ulkopuolinen ei voinut järkyttää.

Myyttisyys verhoaa menuettia alkuajoista lähtien, vaikka sen syntyä onkin pidetty varsin tarkasti dokumentoituna. Yleisen käsityksen mukaan ensimmäisen menuetin tanssi Ludvig XIV rakastajattarensa kanssa Versailles'ssa vuonna 1653 (Taubert 1968, 163). Kuitenkin mm. Eero Nallinmaa $(1982,9)$ on epäillyt tämän tiedon paikkansa pitävyyttä. ${ }^{21}$ Ensimmäisen menuetin koreografian tekijästä on puolestaan ristiriitaisia tietoja. On oletettu, että se olisi ollut Ludvig XIV:n balettimestari Pierre Beauchamp (Thorén \& Kennryd, moniste, 1), mutta Karl Heinz Taubert $(1988,118)$ arvelee, että koreografina olisi voinut olla jopa samaisen menuetin säveltänyt Jean Baptiste Lully. Usein myös sanotaan menuetin kehittyneen ranskalaisesta kansantanssista Poitoun maakunnasta (Horst 1937, 67; Norlind 1941, 59). Kuitenkin menuetti oli erityisesti barokin tanssimestarien luomus, ja sen nimikin tuo esiin ajan tanssi-ihanteet: askeleen piti olla pieni (ransk. menu), jopa pienen pieni (menuett). Jalkojen tuli olla aina lähellä toisiaan. (Sachs 1963, 397.)

Menuetti ei syntynyt yhtäkkiä, vaan se on ollut mahdollisesti useampienkin tanssimestarien kehitelmä. On mahdotonta sanoa tarkkaan, missä vaiheessa se erottautui täysin omaksi kokonaisuudeksi. Kuitenkin menuetin luominen liittyy kiinteästi eurooppalaisen hovitanssikulttuurin muutokseen 1600-luvulla. Vielä 1500- ja 1600-lukujen vaihteessa esimerkiksi Englannin kuningatar Elisabeth suosi tansseja, joihin liittyi fyysisen voiman näyttöä, mm. galliardia ja la voltaa (Rust 1969, 45). Vaikka renessanssin basse danset ja pavanet olivat toki olleet hitaampia ja arvokkaampia, niiden muodollisuus ja yksityiskohtaisuus ei yltänyt siihen, mitä Ludvig XIV:n tanssinopettajat saavuttivat. Menuetti erosikin monista aiemmista tansseista nimenomaan siinä, että sen rakenne oli tarkoin määrätty (Wood 1952, 103).

Tanssin kautta alettiin rakentaa kuria, joka löi leimansa aurinkokuninkaan hoviin vähitellen muutenkin. Aatelisto menetti entisen puoli-itsenäisen asemansa, ja markiiseista, kreiveistä ym. tuli hoviherroja, joiden elämä pyöri kuninkaan ympärillä. Kaikessa tässä tanssitilaisuudet toimivat edelläkävijöinä, ja niiden kautta ruumiit saatettiin

\footnotetext{
${ }^{21}$ Nallinmaa on perustellusti epäillyt ensimmäisen menuetin paikkaa, koska tuohon aikaan kuningas piti vielä hoviaan Louvressa ja Saint-Germainnen Layessa. Versailles'ssa oli metsästyslinna, joka oli tanssiaisten järjestämiseen varsin pieni. Vuonna 1661 Ludvig XIV alkoi järjestää Versailles'n puutarhassa juhlia rakastajattarelleen ja ystävilleen: silloinkin sisätilat olivat liian ahtaat. Lisäksi Nallinmaa huomauttaa, että vuonna 1653 Ludvig oli 15- vuotias ja että kardinaali Mazarini piti vielä voimakkaasti valtakunnan ohjaksia käsissään: näissä olosuhteissa onkin epäilyksenalaista, oliko kuninkaalla vielä rakastajatarta. Sinänsä kyseinen vuosi sopisi muuten hyvin menuetin ensiesitykseksi.
} 
järjestykseen, jota absolutistinen valtio vaati. Tästä syystä tanssinopettajat suosivat omalta osaltaan menuettia: sitä ei pidettykään pelkästään tanssina, vaan se oli hovikulttuuriin liittyvän etiketin ja arvojärjestelmän ruumiillistuma. Juuri se toimi hienostuneiden kohteliaisuuksien ja käytöstapojen kouluna. (Spencer 1985, 8.) Menuetin oppiminen olikin vaikeaa ja aikaa vievää (Norlind 1941, 59).

Barokin hovitanssit muodostivat oman maailmansa tarkoin määrättyine muotoineen ja käyttäytymissääntöineen. Kuningas avasi tanssiaiset kohottautumalla, jolloin kaikki läsnäolijat tekivät samoin. Hän johdatti kuningattaren lattialle tanssin aloituspaikalle, ja muut järjestäytyivät samalla tavoin omille paikoilleen. Ensimmäisenä tanssina oli branle, jonka johtajana hallitsijapari toimi. Tämän jälkeen kukin pari vuorollaan johti tanssia, kunnes kuningas ja kuningatar jälleen olivat ensimmäisinä. Seuraavana oli vuorossa gavotti, joka tanssittiin samanlaisessa branlemuodossa. (Taubert 1988, 28.) Tämän jälkeen alkoivat yksittäisparien tanssit. Ludvig XIV:n aikana hallitsijapari aloitti nämä courantella, Ludvig XV:n aikana menuetilla; tällöin kaikkien läsnäolijoiden tuli seurata tanssia seisten. Tämän jälkeen tanssivat kaikki muut parit arvojärjestyksessä. (Mt. 28-29.) Ennen tanssia ja sen jälkeen tanssijat suorittivat seremonialliset tervehdykset, joista tärkeimmät osoitettiin kuninkaalle.

Tämä hovitanssimuoto omaksuttiin myös Ranskan porvarillisissa piireissä. Tanssiaisissa valittiin yksi pari kuninkaaksi ja kuningattareksi, ja he aloittivat tanssin (Taubert 1988, 29). Tanssin jälkeen kavaljeeri kysyi daamiltaan, ketkä hän halusi nähdä seuraavana tanssimassa, ja valittu pari tuli tanssimaan. Näissä tansseissa toimi myös seremoniamestari, joka huolehti siitä, että kaikki sujui hovietiketin mukaisesti. (Biskop 1993a, 6.) Tanssi tässä muodossa olikin nimenomaan seremoniaa, jossa oikea suoritus oli keskeistä (Eichberg1987, 69). Tanssijat noudattivat tarkasti määrättyjä liikesarjoja ja liikkuivat geometrisen tarkkojen kuvioiden mukaan.

Menuetti yleistyi lähes kaikkialla Länsi-Euroopassa Italiasta Ruotsi-Suomeen. Ranskalainen tanssityyli oli esikuvana useimmissa hoveissa samoin kuin aurinkokuninkaan absolutistinen hallinto ja Versailles. Ranskan tavoin myös monissa muissa maissa porvarit omaksuivat hovin tanssi-tapoja; yhteiskunnallinen hegemonia oli vielä aatelisilla, joiden käyttäytymistä porvarit pyrkivät jäljittelemään. Menuetti edusti konkreettisella tavalla tätä hegemoniaa, joten se oli innokkaan opettelun kohteena jopa tietyissä talonpoikaisissa piireissä. Menuetin valta-asema säilyi koko 1700-luvun ajan, vaikka Euroopassa tapahtui toki muutoksia monella tasolla: absoluuttisesta valtaihanteesta siirryttiin valistusfilosofiaan, barokin jäykkä tarkkuus ja symmetria vaihtui kepeämpään rokokoohon taiteiden alalla, Ruotsi menetti suurvalta-asemansa, johon Preussi taas kohosi, Puola jaettiin, ja se lakkasi olemasta ja lopulta Ranska ajautui Ludvig XIV:n valtakauden lopulla taloudellisen vararikon partaalle, mikä vaikutti yhteiskuntaan syvällisesti johtaen lopulta suureen vallankumoukseen. Menuetin asema oli niin vahva, että vaadittiin todella perusteellista muutosta, että se pystyttiin murtamaan.

Vuonna 1700 menuetti sai klassisen muotonsa, "Menuet de la cour", jonka loi pariisilainen tanssimestari, Beauchampin seuraaja Louis Pécour. (Norlind 1941, 59-60; Thorén \& Kennryd, moniste, 1.) Pécour vakiinnutti Z-kuvion menuetin päävuoroon (Taubert 1968, 165). Tärkeimmäksi askeleeksi puolestaan kohosi samaan aikaan ns. pas de cour, vaikkakin monia muitakin käytettiin sen rinnalla, ja jatkuvasti kehiteltiin uusia (Taubert 1988, 88-93). Pas de cour'n perusrakenne on seuraava (mt. 89): 


$\begin{array}{lll}\text { Tahti } & \text { Tahdinosa } & \text { Liike } \\ & 3 & \text { Plié (polvien jousto). } \\ \text { 1: } & 1 & \text { Askel oikealla jalalla. } \\ & 2 & \text { Plié. } \\ \text { 2: } & 3 & \text { Askel vasemmalla jalalla. } \\ & 1 & \text { Askel oikealla jalalla } \\ & 2 & \text { Askel vasemmalla jalalla. }\end{array}$

Klassisen hovimenuetin rakenne puolestaan on seuraava (Taubert 1968, 175-181):

1. osa Esiintulo ja parin asettuminen tanssitilaan.

Tervehdykset (révérence) läsnäolijoihin päin kääntyneenä.

Tervehdykset omaan paritoveriin päin kääntyneenä.

Kavaljeeri kuljettaa daamin lähtöpaikalle.

2. osa Paikanvaihto Z-kuviossa.

Paluu lähtöpaikoille samassa kuviossa.

3. osa Paikanvaihto Z-kuviossa.

Z-kuvion keskellä "Tour de main": oikeat kädet käsissä

pyörähdys pareittain myötäpäivään.

"Tour de main" vasemmat kädet käsissä vastapäivään.

Paluu paritoverin paikalle.

Paluu lähtöpaikoille Z-kuviossa.

4. osa Paikanvaihto Z-kuviossa.

Z-kuvion keskellä pyörähdys pareittain kädet käsissä myötäpäivään ("tour de deux mains").

Siirtyminen lähtöpaikoille.

Tervehdykset läsnäolijoihin päin kääntyneenä.

Tervehdykset omaan pariin päin kääntyneenä.

Tämä perusmuoto pysyi hallitsevana koko 1700-luvun, vaikkakin tanssinopettajat tekivätkin siihen omia muunnelmiaan (Taubert 1988, 21). ${ }^{22}$ Menuetti oli siis ennen kaikkea sooloparin tanssi, ja sen liikkeissä noudatettiin ankaraa symmetrian ajatusta samalla tavoin kuin esimerkiksi Versailles'n puutarhan sommittelussa.

Halu kontrolloida tanssia pienintäkin yksityiskohtaa myöten johti uuden notaatiojärjestelmän kehittämiseen. Erilaisia tapoja kuvata tanssia oli länsimaissa harrastettu ainakin 1400-luvulta lähtien, mutta ne eivät koskaan olleet mitenkään tarkkoja vaan perustuivat lähinnä tiettyjen perusliikesarjojen symboleihin. Liikkeiden yksityiskohtaista suorittamista ei niistä voinut päätellä. (Guest 1984, 42-46.) Ei ole yllättävää, että uuden järjestelmän luoja oli edellä mainittu Ludvig XIV:n tanssimestari Pierre Beauchamp, vaikkakin sen teki tunnetuksi häntä nuorempi Raoul Auger Feuillet kirjassaan Chorégraphie ou l'Art de Décrire la Danse (1700). Beauchamp-Feuillet'n notaatio oli yksityiskohdiltaan ja tarkkuudeltaan aintulaatuinen, ja sillä kirjoitettuja tanssiohjeita pystytään helposti tulkitsemaan nykyäänkin. Se oli suunniteltu juuri ajan tarpeita sil-

\footnotetext{
${ }^{22}$ Muunnelmia syntyi varsin runsaasti, sillä vuonna 1700 tunnettiin jo noin sata erilaista tapaa tanssia menuettia.
} 
mällä pitäen, ja siitä tuli yksi kaikkien aikojen käytetyimmistä tanssinotaatioista. (Mt. 62-65.)

1700-luvun alusta lähtien julkaistiin runsaasti tanssikirjallisuutta, jonka avulla ajan muotitanssit levisivät hoveista toisiin, ja tämä notaatiojärjestelmä varmisti sen, että tanssien pienimmätkin yksityiskohdat välittyivät eteenpäin. Mielenkiintoista on, että kyseisen notaation valtakausi ajoittuu yhteen menuetin valtakauden kanssa: tanssikulttuurin muutosten myötä se jäi vanhentuneena pois käytöstä 1800-luvun alkuun mennessä. Hieman kärjistäen voisikin todeta, että kyseinen notaatio kehitettiin menuettia ja sen luomaa käyttäytymisjärjestelmää varten ja että menuetin jäätyä pois tanssirepertoaarista se muuttui tarpeettomaksi ja tästä syystä se hävisi.

Notaation käyttö ei kuitenkaan ollut ainoa keino, jolla tanssimista pyrittiin kontrolloimaan painetussa muodossa. Tanssikirjoissa pyrittiin muutenkin selostamaan tanssin kulku mahdollisimman tarkasti:

Man mu $\beta$ vor allem observieren, da $\beta$ ein jeglicher Pas de Menuet jederzeit aus vier, theils steiffen, theils gebogenen Schritten besteht und accuratissime in zwey Drey-Viertel-Tachten der Menuet-Melodien geendigt werden müsse. (Taubert 1988, 83 <G.Taubert: Rechtschaffener Tantzmeister, 1717)

Wann ich dann ein Menuet Pas mache, mus ich in der ersten Coupé die Arme vornen fallen lassen, in Continuirung der andern halben Coupé, und zweyen steiffen Schritten aber wieder zurück werfen. (Taubert 1968, 166 <L. Bonin: Die Neueste Art zur Galanten und Theatralischen Tantz-Kunst, 1712.)

Myös ranskalaisen tanssimestarin Pierre Rameaun (1970, 55-71) kirjassa Maître á Danser kuvataan menuetin kohdalla tanssin askelikkoja, sen korrektia tanssimista, kuinka tanssiin saadaan viehkeyttä ja yhdenmukaisuutta sekä käsien asentoja tanssissa. Siinä myös neuvotaan, kuinka menuettiaskelikko tanssitaan hypäten (contretemps), mikä kirjan mukaan on sopivaa vain nuorille tai keskipainoisille (Rameau 1970, 7173). Hyppyjen käyttäminen menuetissa kuulostaa varsin oudolta, mutta Rameau ei ole ainoa, joka mainitsee siitä: professori Lars Huldén (1984, 7-9) on todennut, että hyppimiseen viittaavat epäsuorasti ruotsalainen tanssinopettaja Sven Henrik Walcke kirjassaan Minnes-Bok uti Dans-Konsten (1782) ja suoraan Carl Michael Bellman epistolassaan numero 9. Huldén päättelee näiden ja muutamien muiden lähteiden perusteella, että hyppymenuetti edusti jotain vaihtoehtoista tanssitapaa, jota esimerkiksi tanssinopettajat eivät hyväksyneet.

Tarkasteltaessa edellä mainittua Bellmanin epistolaa käy todellakin ilmi, että kyse on jostain muusta kuin jäykästä seremoniallisesta tanssista: kuvatussa tilaisuudessa tanssitaan koko yö menuettia erittäin riehakkaassa tunnelmassa (Bellman 1969, 39-42). Olisi houkuttelevaa tehdä sellainen johtopäätös, että Bellmanin kuvaus koskee rokokoon kepeää ilmapiiriä, joka olisi suvainnut vapaampaa tanssia kuin barokin jäykän muodollinen etiketti. Kuitenkin Rameaun huomautukset ovat jo vuodelta 1725, ja se tosiasia, että hän otti ne kirjaansa, osoittaa, ettei kyse suinkaan ollut aivan uudesta ilmiöstä; päinvastoin vaikuttaisi siltä, että tapa oli niin yleinen, että sitä piti alkaa rajoittaa ja kontrolloida, koska se ilmiselvästi rikkoi ammattilaisten ihanteita. Hyppymenuetti ei kuitenkaan ollut ainoa, joka mursi klassisen menuetin ylivaltaa.

1700-luvulla menuetti kehittyi edelleen sekä tanssillisesti että musiikillisesti. Englantilaiset tanssimestarit kehittivät uusia menuettimuunnelmia country dance pohjalta. Tästä syystä ranskalaiset tanssinopettajat matkustivat Lontooseen hakemaan uusia vaikutteita hovitansseihin. Erityisesti nuorten keskuudessa solassa, rajoittamattoman monessa kahden parin ryhmässä tanssittavat tanssit olivat suosittuja. Tanssinopet- 
tajien olikin pakko ottaa niitä ohjelmistoonsa myös Ranskassa. Jo vuodelta 1706 on tieto tanssista Le Menuet á quatre, jossa tanssitaan neljän henkilön ryhmänä. Teoksensa Recueil de danses de Bal esipuheessa R.A.Feuillet kertoi valinneensa vuoden 1707 tanssien joukkoon tämän tanssin, koska se oli saavuttanut niin laajan suosion. Neljän hengen menuettia seurasi pian lisää uusia menuettimuunnelmia ja jo vuonna 1711 julkaistiin Englannissa tanssikirja, johon sisältyivät kolmen, neljän, viiden, kuuden, yhdeksän ja kahdentoista hengen menuetit. (Taubert 1988, 38-39.)

Country dance -pohjaiset menuetit eivät välttämättä aluperin miellyttäneet ranskalaisia tanssinopettajia, mutta asemansa säilyttääkseen heidän oli pakko ottaa niitä ohjelmistoonsa ja kehittää niitä. Vaikka he pyrkivät varsin pitkälle määräämään niiden muodoista ja yksityiskohdista, ne kuitenkin edustivat aivan toisenlaista tanssiasennetta: niissä tanssittiin ryhmässä eikä sooloparina, niiden kuviot olivat "suljettuja" eli niitä ei suunnattu yleisöä vaan toisia tanssijoita kohti ja niissä oli enemmän kosketusta muihin tanssijoihin. Nämä menuettivariaatiot olivat 1700-luvulla erittäin suosittuja, ja erityisesti kahdeksan hengen neliössä tanssittu menuetti (Menuett en huit) oli esikuvana vuosisadan lopulla kehityneelle katrillille (Taubert 1968, 173).

Ranskan vallankumous merkitsi aatelin hegemonian vähittäisen murtumisen alkamista. Vanhan järjestyksen symbolit polvihousuista valtiokirkkoon joutuivat ankaran arvostelun kohteeksi, ja ne syrjäytettiin enemmän tai vähemmän perusteellisesti. Myös menuetti joutui tulilinjalle jopa maissa, jotka virallisesti vastustivat vallankumousta ja myöhemmin Napoleonia. Tällainen oli esimerkiksi Ruotsi, johon Suomi vielä 1800 -luvun ensimmäisinä vuosina kuului. Åbo Tidning -lehdessä 10.1.1801 ilmestyi alunperin saksankielinen artikkeli, jossa ilmaistiin huolestumista menuetin vähäisestä suosiosta nuorison keskuudessa:

Menuet, framför alla andra, medgifwer uttryck af finare känslor; men denne Gracernas dans har i wåra yppiga och yra sällskap blifwit nedsänkt ända til förakt ... Denne dans har förlorat alt behag hos den ungdom, som ej har smak för det verkligen wackra. (Nallinmaa 1982, 313.)

Kirjoitukseen liitettiin kuitenkin vastine, jossa puolustettiin uusia tansseja, ja niiden suosiota:

Först är de ogrundat, at wåra nyare dansar saknar all expresion. Twertom ligger i den et lika talande uttryck af tidens seder som i Polskan och Menuetten. Jag lemnar dessa gammalmodiga dansar i sitt wärde. De woro goda på sin tid; och uttryckte icke illa wåra förfäders tänkesätt och bruk ... men andra tider, andra seder. En sådan dans wore nu mera löjlig för åskådaren, för hwilken den ingenting sade och tröttsam för den dansande, som skulle dö af ledsnad öfwer dess enformighet. (Andersson 1963, XXXV-XXXVI.)

Kirjoituksessa mainitaan vielä, että uudemmat tanssit, joihin kuuluivat långdans, katrilli ja valssi, sopivat paremmin uudelle aikakaudelle ja sen tapoihin. Erityisesti kirjoittaja puolustaa monin paikoin kiistelyä herättänyttä valssia. (Mt. XXXVI.) Kirjoitusten sävystä voi päätellä, että menuetin ja polskan syrjäytyminen oli alkanut jo muutamia vuosia aikaisemmin, viimeistään edellisen vuosisadan loppuvuosina. Kehityksen nopeutta osoittaa se, että 1810-luvulta säilyneissä tiedoissa tansseista Turussa ei ole ollenkaan mainintaa menuetisa. Myös myöhemmistä tiedoista menuetti puuttuu. (Heinricius 1914, 116-127.)

Menuetti ei kuitenkaan heti syrjäytynyt kokonaan edes Ranskassa, jossa se oli jossain määrin suosiossa keisariajan alussa (Nallinmaa 1982, 68). Entisen valta-aseman se oli joka tapauksessa menettänyt: Wienin kongressissa 1814 muodissa olivat valssit 
ja poloneesit, ja yksittäisten ryhmien tanssimat menuetit hymyilyttivät ranskalaisia ja englantilaisia, joiden seuraelämään tällainen "sievistely" ei enää kuulunut (Taubert 1988, 127).

Menuetti jatkoi silti sinnittelyään koko 1800-luvun ajan. Osana tanssinopettajien ohjelmistoa se säilyi vielä pitkään (Taubert 1968, 172). Sitä pidettiin edelleenkin hienostuneen liikkumisen ja täydellisen viehkeyden kouluna:

In ihr ruhen alle schönen Eigenschaften eng vereint, die sie zu einem Ganzen bildet, als: Majestät, edler Anstand, Grazie, Würde, Ehrfurcht, Galanterie und Delicatesse ... Um Bälle zu eröffnen, eignet sich wohl kein Tanz besser, als die Menuet... (Taubert 1988, $19<$ <.A.Helmke, Neue Tanz- und Bildungsschule 1829.)

Vaikka kuitenkin klassinen menuetti pysyi 1800-luvun tanssikirjojen ohjelmistossa, sitä pyrittiin myös muuttamaan ajan henkeen paremmin sopivaksi.

Viimeisen kukoistuksensa menuetti koki vanhoillisen Saksan keisarihovissa, jossa vuonna 1892 otettiin käyttöön Menuet de la cour. Tätä tanssittiin W.A. Mozartin säveltämän Don Giovanni -oopperasta peräisin olevan menuetin säestyksellä. (Taubert 1988 , 128.) Monine vuoroineen tämä tanssi oli etääntynyt jo varsin kauaksi klassisesta menuetista (Sachs 1963, 407). Tämän jälkeen menuetti poistui lopullisesti yläluokan sosiaalisen tanssin tilaisuuksista jääden lähinnä historiallisten tanssien harrastajien sekä teatterin ja elokuvan käyttöön.

\section{Menuetin monet merkitykset}

Menuetin tutkimuksessa on yleensä tuotu esiin sen symbolisia aspekteja. Tämä on toisaalta ymmärrettävää, sillä valtaosassa kirjallisuutta ja muita kirjallisia dokumentteja korostetaan pelkästään menuetin seremoniallista luonnetta. Kirjoittajat olivat usein tanssinopettajia, ja he pyrkivät muokkaamaan tanssia kontrolloituun suuntaan vastustaen tiukasti yrityksiä siirtyä vapaampaan tyyliin. Vastakkaisen näkökulman edustajilla ei ollut tarvetta tai kiinnostusta ruveta levittämään mielipiteitään: he vain tanssivat. Koska emme voi palata ajassa taaksepäin, kirjalliset dokumentit ovat käytännössä ainoita, joihin voimme nojautua. Tästä syystä on syntynyt harhakuva menuetista pelkästään äärimmäisen muodollisena tanssina. Bellmanin epistolat ovat lähes ainoita lähteitä, joissa ilmenevät menuetin vapaammat muodot.

Kuitenkin sijoittamalla eri lähteet yhteiskunnalliseen ja historialliseen yhteyteensä niistä voi paljastua enemmän, kuin aluksi luulisikaan. Rameaun esimerkki tuo esiin sen, kuinka tanssioppaan rajoitukset voivat paljastaa ei-toivottuja käytäntöjä. Tanssityyliä ei tarvitsisi kontrolloida, jos kukaan ei sitä käyttäisi. Toisaalta voidaan ajatella, että tanssi ei pystyisi säilymään edes ylhäisten tukijoidensa avulla, jos se olisi pelkästään hyvin jäykän seremoniallisessa käytössä. Menuetin suosio on varmasti osaltaan johtunut myös sen vapaammista tyyleistä ja variaatioista, vaikka niistä tanssinopettajat ovat usein vaienneet. Kaiken kaikkiaan menuetti voidaan sijoittaa varsin leveästi akselille vapaa kokeminen - abstrakti symbolismi.

Ääripäissä ovat hovin seremonioissa tansittu menuetti ja hyppymenuetti. Mielenkiintoista on se, että molempien merkitykset ja jopa vastakkainasettelu ovat säilyneet jossain määrin aina nykyaikaan asti. Seremoniallisen menuetin symboliikka pysyi pitkään lähes muuttumattomana senkin jälkeen, kun sen käyttö varsinaisesti loppui lähes kokonaan; 1800-luvun tanssikoulut välittivät symboliikan eteenpäin tälle vuosisa- 
dalle, ja nykyaikana se heijastaakin vallitsevaa kuvaan menuetista. Hyppymenuetti on puolestaan säilynyt Suomessa nykyaikanakin tanssittavassa menuetissa Uudenkaarlepyyn seudulla. On mahdotonta sanoa, onko tällä varsinaista yhteyttä 1700-luvun hyppymenuettiin vai onko se paikallinen muunnelma. Rakenteelliset yhtäläisyydet ovat kuitenkiin niin selviä, ettei kyse ole välttämättä pelkästä sattumasta. Joka tapauksessa hyppymenuetin ja rauhallisemman menuetin välinen vastakkaisuus on ollut ilmeinen ainakin koko tämän vuosisadan, todennäköisesti jo aikaisemminkin: hyppymenuettia ovat vastustaneet kyseisellä seudulla vanhemmat ihmiset ja laajemmassa yhteydessä kansantanssin harrastajat, koska se ei ole sopinut arvokkaan tanssin kuvaan. Kuitenkin hyppymenuetti on ollut paikoin erittäin suosittu, ja nykyäänkin se kuuluu menuetin harrastajien ohjelmistoon. Hyppymenuetti on fyysisesti raskas ja nopean temponsa vuoksi myös vaikeasti hallittava tanssi, ja siinä ruumiillinen kokeminen muiden tanssijoiden kanssa saavuttaa helposti suorastaan "hurmoksen", kuten eräs munsalalainen nuorukainen kirjoitti vuosisadan alussa (SLS 311, 17).

Näiden kahden väliin sijoittuvat menuetin country dance -muunnelmat. Ne olivat ilmeinen uhka ranskalaisille tanssinopettajille, mutta nämä pystyivät ottamaan ne kontrollinsa alle. Niiden kehitys 1700 -luvulla olikin täysin ranskalaisten tanssimestarien käsissä. Näissä menueteissa symboliikka ei liikkunut enää niin abstraktilla tasolla kuin klassisessa menuetissa: ne eivät kuvastaneet itsevaltaisen kuninkaan ehdotonta asemaa yhteiskunnassa. Niissä sallittiin vapaampaa seurustelua, ja ne olivatkin hyvin "sosiaalisia" tansseja. Kuitenkin ne olivat edelleen muodollisia ja ainakin vuoroiltaan tarkasti määrättyjä, vaikka liikkuminen ei ollutkaan enää niin äärimmäisen kurinalaista kuin aiemmin. Niitäkään ei oppinut vain tulemalla mukaan tanssiin, vaan siihen vaadittiin ammatitaitoista ohjausta. Tanssinopettajat pitivät näin paikkansa hovissa ja saivat hallitsijat vakuuttumaan asemansa tärkeydestä vallitsevan järjestyksen tukipilareina.

Menuetti oli siis merkittävä tekijä yhteiskunnallisessa todellisuudessa 1600-luvun lopulta aina 1800-luvun alkuun asti. Hovin seremonioissa se oli kuin kurinpitoväline, jolla aatelisten ruumiit "pakotettiin" kuningaskeskeiseen maailmanjärjestykseen. Toisaalta se oli kuitenkin myös suosittu tanssi, jossa saavutettiin sanallisen ilmauksen ylittäviä kokemuksia; se oli varsin "lihallinen" tanssi. Joka tapauksessa menuetti osoittaa, kuinka tanssi pystyy toimimaan ruumiillisuuden pohjalle rakentuvan sosiaalisen todellisuuden keskeisenä vaikuttajana jopa länsimaisessa yhteiskunnassa.

\section{Lähteet}

\section{Arkistolähteet}

SKS (Suomalaisen Kirjallisuuden Seuran Kansanrunousarkisto) Harju, Otto 2935. Käsikirjoitus.

SLS (Svenska Litteratursällskapet i Finland, Folkkultursarkivet) 311. Folkhögskolan i Kronoby 1920. Kirjoitelmia aiheesta Ur ungdomens nöjesliv.

\section{Monisteet}

McClary, Susan 1993. Unruly Passions and Courtly Dances: Technologies of the Body in Baroque Music. The 1993 Donald J. Grout Memorial Lecture, Cornell 
University. Moniste.

Thorén, Kerttu \& Kennryd, Folke. Menuetten genom seklerna. Moniste. Sisältää materiaalia menuettia käsittelevään tanssikurssiin.

\section{Painetut lähteet}

Abu-Lughod, Lila 1991. Writing Against Culture. Teoksessa Recapturing Anthropology. Ed. Richard G. Fox. Santa Fe: School of American Research Press.

Andersson, Otto 1963. Inledning. Teoksessa Finlands svenska folkdiktning VI Folkdans A1. Äldre dansmelodier. Helsingfors: Svenska Litteratursällskapet i Finland.

Bellman, Carl Michael 1962. Fredmans epistlar. Solna: Prisma.

Berger, Peter L. \& Luckmann, Thomas 1987. The Social Construction of Reality. A Treatise in the Sociology of Knowledge. (1. painos 1966, USA.) Great Britain: Penguin Books.

Biskop, Gunnel 1993. Menuetten och dess öden I, Folkdansaren, XXXIX årg. (6), 4-6.

Bloch, Maurice 1986. From Blessing to Violence. History and ideology in the circumcision ritual of the Merina of Madagascar. USA: Cambridge Univeristy Press.

Bourdieu, Pierre 1984. Distinction: A Social Critique of the Judgement of Taste (alkuteos La Distinction: Critique sociale du jugement, 1979). USA: Harvard University Press.

Combs-Schlling, M.E. 1989. Sacred Performances. Islam, sexuality, and sacrifice. USA: Columbia University Press.

Eichberg, Henning 1987. Liikuntaa harjoittavat ruumiit. Kohti ruumiin ja urheilun uutta sosiaalitiedettä. Jyväskylä: Vastapaino.

Espeland, Wigdis Jorunn 1991. Det grundleggjande Rörelsemönstret $i$ Norsk Folkedans som kulturell faktor, Nordisk förening för folkdansforsknings Brev 14. Stockholm.

Foucault, Michel 1980. Tarkkailla ja rangaista. (Alkuteos Surveiller et punir.) Helsinki: Otava.

Geertz, Clifford 1973. The Interpretation of Cultures. Selected Essays by Clifford Geertz. New York: Basic Books.

Giurchescu, Anca 1987. The Dance Discourse. Dance Suites and Cycles of Romania and elsewhere in Europe. Dance Studies, vol. 11, ed. Roderyk Lange. Jersey: Centre for Dance Studies.

Guest, Ann Hutchinson 1984. Dance Notation. The process of recording movement on paper. Great Britain: Dance Books.

Hanna, Judith Lynne 1979. To Dance is Human. A Theory of Nonverbal Communication. Austin: The University of Texas Press.

Hanna, Judith Lynne 1988. Dance, Sex and Gender. Signs of Identity, Dominance, Defiance, and Desire. Chicago: The University of Chicago Press.

Heikel, Yngvar 1938. Inledning. Teoksessa Finlands svenska folkdiktning VI Folkdans B. Dansbeskrivningar. Helsingfors: Svenska Litteratursällskapet i Finland.

Heinricius, G. 1914. Från samhällslivet $i$ Åbo 1809-1827. Helsingfors.

Hoppu, Petri 1997. Menuetin levinneisyys Suomessa. Teoksessa Kansantanssi 
arkistoissa. Toim. Antti Koiranen. Tampere.

Horst, Louis 1987. Pre-Classic Dance Forms (1. painos 1937). Princeton, NJ:

Princeton Book Company.

Huizinga, Johan 1984. Leikkivä ihminen. (Alkuteos Homo Ludens, 1938.) Porvoo: WSOY.

Huldén, Lars 1984. Får man hoppa i menuetten? Folkdansaren. XXXI årg. (6), 3-10.

Kealiinohomoku, Joann W. 1997. Dance, Myth and Ritual in Time and Space, Dance Research Journal vol. 29 (1), 65-72.

Klemetti, Heikki 1932. Kuortaneen vaiheita sanoin ja kuvin. Muistojulkaisu pitäjän 300-vuotisjuhlaan 1932. Porvoo: WSOY.

Knuuttila, Seppo 1994. Tyhmän kansan teoria. Helsinki: Suomalaisen Kirjallisuuden Seura.

Kurkela, Vesa 1989. Musiikkifolklorismi \& järjestökulttuuri. Kansanmusiikin ideologinen hyödyntäminen suomalaisissa musiikki- ja nuorisojärjestöissä. Suomen etnomusikologisen seuran julkaisuja 3. Helsinki: Suomen etnomusikologinen seura.

Lange, Roderyk 1976. Some Notes on the Anthropology of Dance. Dance Studies vol. 1. Jersey: Centre for Dance Studies.

Leisiö, Timo 1992. Rituaali ja tanssi. Antropologinen näkökulma. Musiikin suunta 14. vsk. (4), 2-30.

Nallinmaa, Eero 1982. Barokkimenuetista masurkkaan. Sävelmätutkimuksia. Tampere.

Norlind, Tobias 1941. Dansens historia med särskild hänsyn till dansen i Sverige. Stockholm: Nordisk Rotogravyr.

Parviainen, Jaana 1994. Tanssi ihmisen eksistenssissä. Filosofinen tutkielma tanssista. Tampere: Tampereen yliopisto.

Pohjola-Vilkuna, Kirsi 1995. Eros kylässä. Maaseudun luvaton seksuaalisuus vuosisadan vaihteessa. Helsinki: Suomalaisen Kirjallisuuden Seura.

Rameau, Pierre 1970. The Dancing Master. (Alkuteos Maitre á Danser, 1725.) USA: Dance Horizons.

Royce, Anya Peterson 1977. The Anthropology of Dance. USA: Indiana University Press.

Rundt, Dennis 1992. Munsalaradikalismen. En studie i politisk mobilisering och etablering. Åbo: Åbo akademis förlag.

Rust, Frances 1969. Dance in Society. An analysis of the relationship between the social dance and society, in England, from the middle ages to the present day. Prescot UK: Routledge \& Kegan.

Sachs, Curt 1963. World History of Dance. New York: W.W.Norton \& Company.

Saha, Hannu 1996. Kansanmusiikin tyyli ja muuntelu. Kaustinen: Kansanmusiikkiinstituutti.

Sarmela, Matti 1969. The Reciprocity Systems of the Rural Society in the FinnishKarelian Culture Area. FF Communications n:o 27. Helsinki: Suomalainen Tiedeakatemia.

Spencer, Paul 1985. Preface and Introduction: Interpretations of the Dance in Anthropology. Teoksessa Society and the Dance. Ed. Paul Spencer. Cambridge University Press.

Tambiah, Stanley J. 1985. Culture, Thought, and Action: An Anthropological Perspective. Cambridge, Mass.: Harvard University Press.

Taubert, Karl Heinz 1968. Höfische Tänze. Mainz: Pan.

Taubert, Karl Heinz 1988. Das Menuett. Zürich: Pan. 
Turner, Victor W. 1969. The Ritual Process. Structure and Anti-Structure. New York: Aldine Publishing Company.

Turner, Victor W. 1983. On the Edge of the Bush. Anthropology of Experience. USA.

Ward, Andrew H. 1993. Dancing in the Dark: Rationalism and Neglect of Social Dance. Teoksessa Dance, Gender and Culture. Ed. Helen Thomas. Chippenham: Macmillan.

Varto, Juha 1996. Lihan viisaus. Tampere: Tampereen yliopisto.

Wood, Melusine 1952. Historical Dances. London: The Imperial Society of Teachers of Dancing Incorporated.

Åkerblom, Bror 1973. Munsala sockens historia. Munsala: Munsala kommun. 